\title{
Gradhiva
}

GRADHIV

Revue d'anthropologie et d'histoire des arts

19 | 2014

"L'Atlantique Noir » de Nancy Cunard. Negro Anthology $1931-1934$

\section{Vers une image « authentique » de l'Afro- Américain ? Photographies, presse militante et documentaire social (1910-1940)}

Moving towards an "authentic" image of Afro-Americans? Photographs, the activist press and social documentaries (1910-1940)

Julie Jones

\section{(2) OpenEdition}

\section{Journals}

Édition électronique

URL : http://journals.openedition.org/gradhiva/2791

DOI : 10.4000/gradhiva.2791

ISSN : 1760-849X

Éditeur

Musée du quai Branly Jacques Chirac

Édition imprimée

Date de publication : 1 mars 2014

Pagination : 104-131

ISBN : 978-2-35744-073-9

ISSN : 0764-8928

Référence électronique

Julie Jones, « Vers une image « authentique » de l'Afro-Américain ? Photographies, presse militante et documentaire social (1910-1940)», Gradhiva [En ligne], 19 | 2014, mis en ligne le 01 mars 2017,

consulté le 10 décembre 2020. URL : http://journals.openedition.org/gradhiva/2791 ; DOI : https:// doi.org/10.4000/gradhiva.2791 
迹

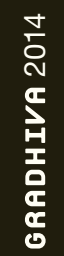

19 


\section{Vers une image "authentique " de l'Afro-Américain?}

Photographies, presse militante et documentaire social (1910-1940)

par Julie Jones

Les nombreuses photographies illustrant la partie «Amérique » de Negro Anthology (1934) témoignent de la volonté de Nancy Cunard d'ancrer son ouvrage, et plus largement, la vision qu'il donne de l'AfroAméricain, dans une contemporanéité. Ses choix d'illustrations, tant par leurs aspects formels qu'iconographiques, révèlent en effet sa connaissance des nouveaux espaces de représentation positive de la communauté afro-américaine offerts par le développement de la presse illustrée (de photographies) à partir du début du $x x^{e}$ siècle, et pendant toute la Renaissance de Harlem. Sa volonté d'établir une image « authentique » de l'Afro-Américain fait par ailleurs parfaitement écho aux utopies défendues par les praticiens du documentaire social dans les années 1930, depuis les photographes affiliés à la Workers' Film and Photo League, jusqu'aux membres de la Farm Security Administration. 
1. Nancy Cunard, $1^{\text {er }}$ avril 1931 , citée in Hugh Ford (éd.), Negro: An Anthology, "Introduction", 2002: XVII

2. L'expression «nouveau Nègre " est communément utilisée par les personnalités associées à la Renaissance de Harlem au début du $x x^{e}$ siècle. Le milieu des années 1920 est généralement considéré comme une période décisive pour ce mouvement qui œuvre à l'émancipation culturelle, intellectuelle, sociale, économique et politique des Noirs américains : en 1925 est publié un numéro spécial de The Survey consacré à Harlem, dirigé par Alain Locke (cf. infra), et quelques mois plus tard paraît une importante anthologie de textes du même auteur intitulée The New Negro. An Interpretation.

3. Cf. W.E.B. Du Bois, "Black America", in Cunard (éd.) 1934 : 148-152.

\section{ci-contre}

\section{fig. 1}

Photographies anonymes illustrant l'article non signé "Our Graduates », in The Crisis, juillet 1917, 14 (3), p.115. The Modernist Journals Project - Brown University, Rhode Island, USA. The CRISIS Publishing Company, Inc. (C) 2014
Si l'apparition de la photographie au milieu du xIxe siècle engendre de nouvelles formes stéréotypées de représentation de l'Afro-Américain, elle permet également de les contester. Pendant les trois premières décennies du xxe siècle, grâce à l'essor de la presse et des ouvrages illustrés, de nombreuses publications afro-américaines voient le jour sur l'ensemble du territoire des États-Unis; par le texte comme par l'image, elles dénoncent les inégalités et les violences subies et affirment une identité communautaire. Plusieurs publications «blanches» soutiennent également leur cause: sympathisants et communistes en particulier contribuent largement à la défense des droits de la communauté afro-américaine. Dans les années 1930, celle-ci est aussi un des sujets de prédilection des photographes du documentaire engagé, pour la plupart soutenus par la politique du New Deal.

En quoi la partie «Amérique» de Negro, publiée en 1934 par Nancy Cunard, est-elle emblématique des formes et des paradoxes de ces nouveaux espaces de représentation positive de l'Afro-Américain? Comment la volonté de l'auteur d'établir une image "authentique» de celui-ci s'inscrit-elle par rapport aux utopies défendues par le documentaire social des années 1930 ?

Dans un premier temps, il s'agira d'éclairer la relation complexe qu'entretient Cunard avec la culture iconographique de la Renaissance de Harlem en comparant ses choix pour Negro avec les images diffusées dans les périodiques afro-américains ou pro-afro-américains pendant les années 1910 et 1920; puis nous montrerons comment la recherche d'«authenticité » prônée par Cunard inscrit Negro dans le courant du documentaire social des années 1930. Dès 1931, elle annonce que l'ouvrage sera abondamment illustré, "entièrement documentaire 1", excluant toute idéalisation ou sentimentalisme; l'exhaustivité, les enquêtes de fond, la préférence donnée au réalisme de la photographie plutôt qu'au dessin témoignent de son inscription dans ce courant.

\section{Le “nouveau Nègre ${ }^{2}$ ": pour une nouvelle identité visuelle de l'Afro-Américain (1910-1930) \\ Dignité et violence dans The Crisis: A Record of the Darker Races}

La revue mensuelle The Crisis, organe officiel de la National Association for the Advancement of Colored People (NAACP), est emblématique des questionnements et des partis pris sur la représentation de l'Afro-Américain par sa propre presse au début du $x x^{e}$ siècle aux États-Unis. Cette publication est créée en 1910 à New York par W.E.B. Du Bois (1868-1963), historien et écrivain politique, cofondateur de la NAACP I'année précédente, et dont Cunard inclut un texte dans $\mathrm{Negro}^{3}$. Informant ses lecteurs sur les événements contemporains, la revue accueille également, à partir du début des années 1920, des écrivains associés à la Renaissance de Harlem. Conformément au programme de la NAACP - combattre les préjugés racistes et défendre l'égalité des droits -, la revue publie des photographies qui documentent les accomplissements et les réussites des Afro-Américains dans les domaines de l'éducation, du logement, de la politique et du commerce. Comme le fera plus tard Cunard dans son ouvrage, la plupart des articles sont illustrés du portrait photographique de leurs auteurs et/ou de leurs protagonistes. Ces visages font presque systématiquement face à l'opérateur et interpellent directement le lecteur, dispositif qui permet d'augmenter l'effet de présence et d'individualiser la voix du texte publié (fig. 1). 


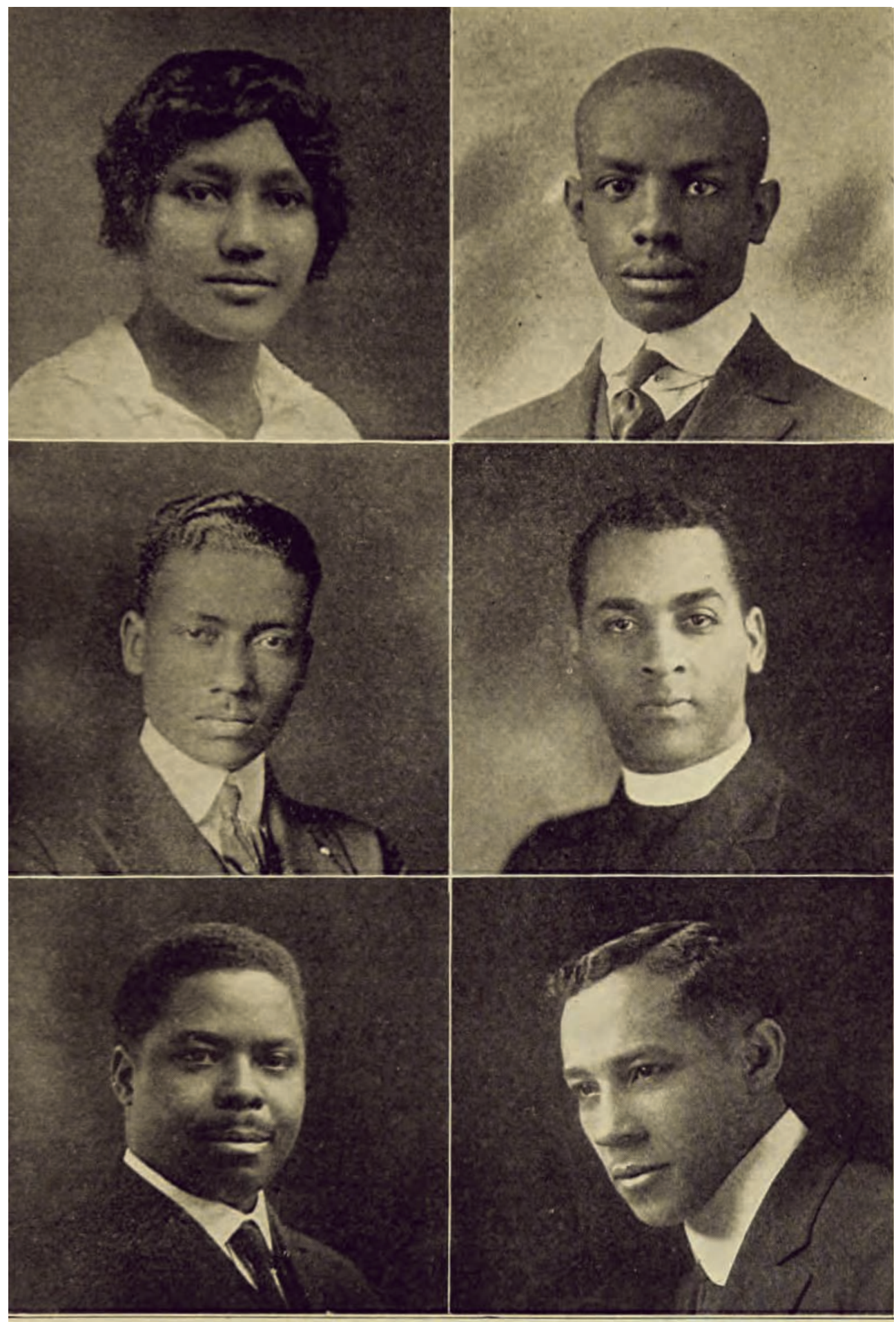

RECIPIENTS OF HIGHER DEGREES.

MISS H. E. WILSON,

M. A., University of Michigan.
L. D. TURNER,
E. E. TYLER,
M. A., Columbia.

KELLY MILLER, JR.,

M. A., Clark.

E. W. DANIEL,

M. A., N. Y. University,

E. M. A. CHANDLER,

$\mathrm{Ph}$. D., Illinois. 


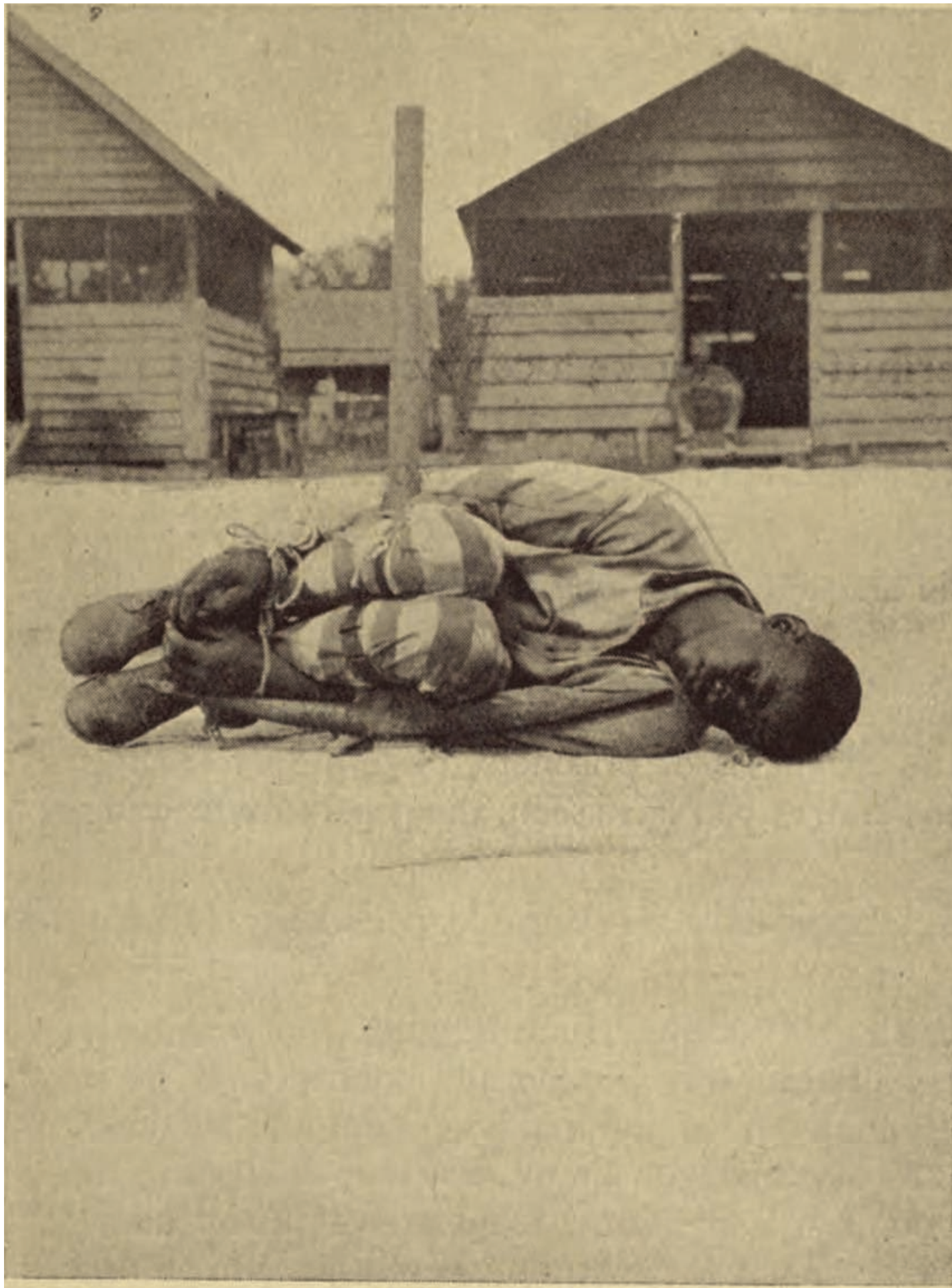

"Hog-tied"

A convict boy in the Seminole County stockade, Georgia Photo copyrigbt by Jobn Spivak. Reproduced by courtesy of Jobn Spivak 
Ces images «positives» sont souvent mises en regard avec d'autres, qui témoignent des atrocités vécues par les Afro-Américains ${ }^{4}$. Dans Negro, en revanche, si un grand nombre d'articles commentent ces brutalités, le choix des photographies témoigne d'une retenue quant à la représentation de la violence: on n'y trouve que deux photographies de lynchages ${ }^{5}$. D'autres l'évoquent, mais sous une forme plutôt «épurée», comme celles qui illustrent un texte de John Spivak, journaliste blanc sensible à la cause afroaméricaine et auteur du roman Georgia Nigger paru en $1932^{6}$, résultat d'une enquête menée en 1930 et 1931 sur les prisons, les camps de travail et les chaînes de forçats en Géorgie; en appendice, Spivak publie des documents et des images qu'il juge nécessaires pour “établir la crédibilité de l'œuvre ${ }^{7}$ ». Les photographies, prises par le journaliste lui-même, montrent des scènes de torture subies par les prisonniers. Certaines bénéficient d'un point de vue décalé ou d'un décadrage qui en accentue l'aspect dramatique (fig. 2), mais la plupart sont d'une froide objectivité qui contraste avec la violence du sujet comme avec les légendes descriptives de la torture. L'intégration par Cunard de certaines images de Spivak dans Negro s'explique sans doute par sa volonté d'éviter toute victimisation. Cette attitude «distanciée» est symptomatique d'un changement dans la représentation de ce type de sujet dans la presse: si quelques publications des années 1920 continuent de se servir de la violence des images et des juxtapositions que l'on trouvait dans The Crisis, cette rhétorique de la dénonciation s'affaiblit progressivement au profit de représentations plus positives; on cherche ainsi à contrer les effets négatifs de l'exhibition de l'horreur, dont en premier lieu sa banalisation ${ }^{8}$. Cette tendance s'explique en partie par le fait que la défense du nouveau Nègre chez les intellectuels pro-afro-américains repose sur la dénonciation de l'image dégradante du «Nègre» construite et véhiculée par la culture populaire américaine, qu'il soit humilié ou objectivé par son statut de victime.

\section{Le pittoresque et l'idéalisme «noirs » dans The Survey}

La position défendue par la revue progressiste The Survey est exemplaire de ce tournant. Multipliant les articles dénonciateurs des mauvaises conditions de travail des ouvriers et de l'exploitation de celui des enfants, cette revue «blanche» consacre également des enquêtes aux problèmes du logement, au vote des femmes, aux conditions de vie en prison, et aux discriminations dont souffrent les immigrants et les Afro-Américains. Les images de ces derniers dans la revue penchent résolument vers une esthétique «pittoresque», notamment celles choisies pour la série d'articles «The homes of the free» parue entre octobre 1923 et février 1924. Destinés à tous ceux qui s'intéressent à «l'éducation rurale comme à ceux qui souhaiteraient comprendre ce qui est à l'origine de notre problème racial, et ce que l'avenir nous réserve ${ }^{9}$ ", ces textes sont signés Rossa B. [Belle] Cooley, ancienne éducatrice afro-américaine du Hampton Institute ${ }^{\mathbf{1 0}}$ (Virginie), alors à la tête de la Penn School11 (Caroline du Sud). La composition et l'iconographie de ces images reposent sur un symbolisme fort, transmettant des représentations positives. Si elles se détournent des clichés dégradants, l'idéalisation des sujets photographiés y est cependant fondée sur la même logique que celle du stéréotype. La première photographie donne le ton: on y voit un portrait de femme, son nouveau-né dans les bras, signé Lewis $\mathrm{H}$. Hine, collaborateur de la revue connu pour son engagement auprès des immigrants et des ouvriers, et pour sa dénonciation du travail des enfants.
4. Sur cette juxtaposition, voir l'étude de Carroll 2005.

\section{Cunard (éd.) 1934 : 33, 38.}

6. John Spivak, «Flashes from Georgia chain gangs " et "From Georgia Nigger ", in Cunard (éd.) 1934: 210-216, 216-222.

7. Spivak [1932], cité in Spivak 2012, "Introduction»: XIX.

\section{Carroll 2005: 15.}

9. "A series of consuming interest to every one concerned in rural education as well as to those who would understand all that lies behind and ahead of what we call our race problem. » (Cooley 1923b: 148, notre traduction)
10. Le Hampton Normal and Agricultural Institute est fondé en 1868 par le généra Samuel Armstrong. Destiné à l'éducation morale, pratique et industrielle des Afro-Américains du sud des États-Unis, l'enjeu de cet établissement, subventionné par de riches donateurs, dont John D. Rockefeller, est de permettre l'autonomie des membres de cette communauté. Vers 1900, il compte plus d'une centaine de professeurs, et plus de 1400 étudiants. Voir http://www.vahistorical.org, "Hampton Institute and Booker T. Washington ".

11. La Penn School est une des premières écoles "noires" dans le sud des États-Unis. Fondée en 1862 par Laura Towne, elle se trouve sur l'île de Saint Helena, en Caroline du Sud.

\section{ci contre}

fig. 2

John Spivak, photographie pour son article «Flashes from Georgia chain gangs ", in Cunard (éd.) 1934, p. 214 (C) John Spivak Estate. 


\section{Cooley 1923a: 4.}

13. Il publie par ailleurs plusieurs de ses images au début $d u x x^{e}$ siècle dans des ouvrages de l'auteur afro-américain Paul Laurence Dunbar (1872-1906).

14. Cooley 1923b: 150 ; Cooley 1923a: 9.

15. Les questions d'éducation rurale et industrielle des Afro-Américains occupent une importante place dans Negro Anthology, comme en témoigne notamment le long portrait consacré à Booker T. Washington. Cf. The Rev. Arthur E. Massey, «Dr. Booker T. Washington. Negro educationalist and founder of the Tuskegee Institute ", in Cunard (éd.) 1934 : 24-28.

16. Alain Locke, «Sterling Brown: The new Negro folk-poet ", in Cunard (éd.) 1934: 111-115.

17. «[...] it was the first issue in which African Americans were able to represent themselves. But the issue also included some of the trademarks of the publication, such as its ethnographic nature. Its visual texts, photographs and two series of portraits by Winold Reiss, depict African Americans as exotic objects of study, mute before the spectator. " (Carroll 2005: 17 , notre traduction)
18. Anon., "Harlem types. Portraits by Winold Reiss ", in Locke 1925a: 651-654: «Four portraits of Negro women ", ibid. : 685-688.

19. "Caricature has put upon the countenance of the Negro the mask of the comic and the grotesque, whereas in deeper truth and comprehension, nature or experience have put there the stamp of the very opposite, the serious, the tragic, the wistful. " (Ibid. : 652, notre traduction)

20. "Harlem, or any Negro community, spreads a rich and novel palette for the serious artist. " (Ibid. : 651 , notre traduction)

21. "[...] seeking always the folk character back of the individual, the psychology behind the physiognomy "; «Without loss of naturalistic accuracy and individuality [...]". (Ibid. : 653, notre traduction)
La puissance symbolique de cette madone à l'enfant est renforcée par la légende qui interpelle le lecteur sur le thème de la naissance, dans son sens le plus large ${ }^{\mathbf{1 2}}$. À plusieurs reprises dans ces articles, on joue sur le pittoresque photogénique du sujet afro-américain, comme dans les photographies signées Leigh Richmond Miner (1864-1935), un éducateur du Hampton Institute qui entreprend, à partir de 1900, une enquête photographique sur la Penn School ${ }^{13}$. Beaucoup d'entre elles décrivent le travail aux champs par des portraits ou des plans larges incluant des paysages: très composés, presque picturaux dans l'équilibre des formes, des lumières et des tonalités, ces clichés s'inscrivent dans la tradition du naturalisme photographique. Les légendes choisies renforcent souvent par ailleurs le caractère dramatique du sujet ${ }^{\mathbf{1 4}}$. Ainsi, si les Afro-Américains sont physiquement et symboliquement intégrés à cet élément constitutif de l'identité nord-américaine qu'est la ruralité, les images les représentant reposent néanmoins sur une forte idéalisation et une invitation à la contemplation qui tendent à les rendre passifs et sans voix aux yeux du lecteur. Dans Negro, les photographies choisies pour illustrer les articles touchant aux questions d'éducation rurale de la communauté afro-américaine comme à l'autonomie de production et de gestion à laquelle elle lui permet d'accéder fonctionnent au contraire sur une rhétorique de l'objectivité. Prises également par un éducateur du Hampton Institute (John Baptist Pierce), elles refusent dramatisation et symbolisme, et témoignent davantage du souci de véracité qui marque l'ensemble de l'iconographie de l'ouvrage. Le choix des légendes, strictement descriptives, appuie ce portrait réaliste des cultivateurs ${ }^{\mathbf{1 5}}$.

On retrouve ce type de représentation équivoque dans les illustrations du numéro spécial de mars 1925, Harlem. Mecca of the New Negro, dirigé par l'écrivain et philosophe afro-américain Alain Locke (également présent dans Negro ${ }^{16}$ ). Comme l'analyse Anne Elizabeth Carroll, si ce numéro de The Survey était le premier «dans lequel des Afro-Américains pouvaient se représenter eux-mêmes», il portait néanmoins «quelques-unes des marques de fabrique de la publication, dont sa nature ethnographique». Les AfroAméricains y sont ainsi décrits "comme des objets d'étude exotiques, muets devant le spectateur ${ }^{\mathbf{1 7}}$ ». En effet, certaines des images choisies, bien que visant à contrer les représentations habituelles, véhiculent malgré tout les mêmes catégories et généralisations que celles des stéréotypes dégradants qu'elles combattent. Cette position ambiguë se retrouve en particulier dans deux portfolios de dessins signés Winold Reiss consacrés aux «types de Harlem », et à «quatre portraits de femmes noires ${ }^{\mathbf{1 8}}$ » (fig. 3). Dans un court texte anonyme accompagnant le premier portfolio, il est expliqué que les portraits de Reiss visent à dénoncer «le masque du comique et du grotesque» pour en révéler, à l'opposé, le «tragique» ou le «mélancolique $\mathbf{1 9}^{\mathbf{1 9}}$, et mettre en avant la diversité des «types» de Harlem. Mais cette diversité reste présentée d'une manière volontairement photogénique: «Harlem, comme toute communauté nègre, offre à l'artiste professionnel une riche et inédite palette ${ }^{20}$. " Par ailleurs, grâce à une recherche constante "de la caractéristique populaire derrière l'individu, la psychologie derrière la physionomie», Reiss offrirait ici des portraits respectant «la précision réaliste et l'individualité » des personnes $\mathbf{2 1}$. 


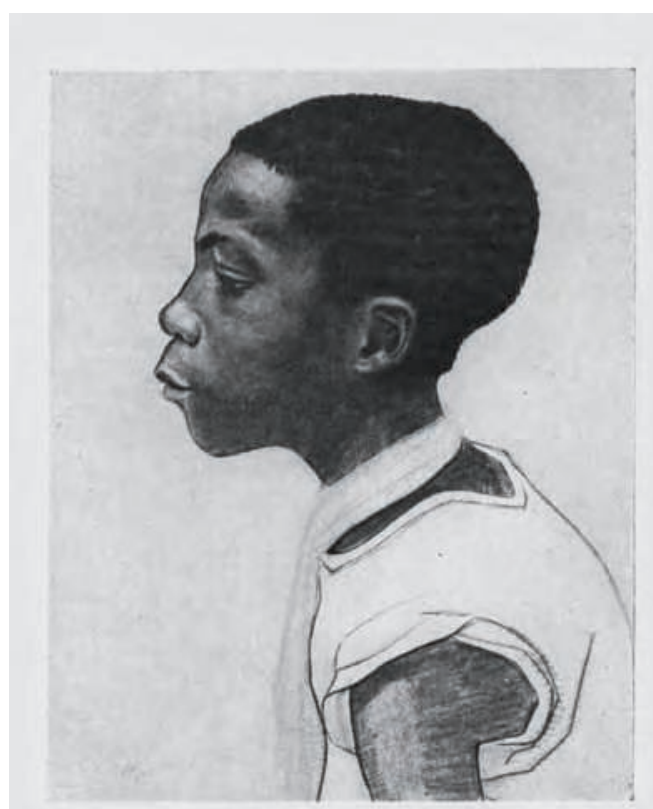

A Boy Scout

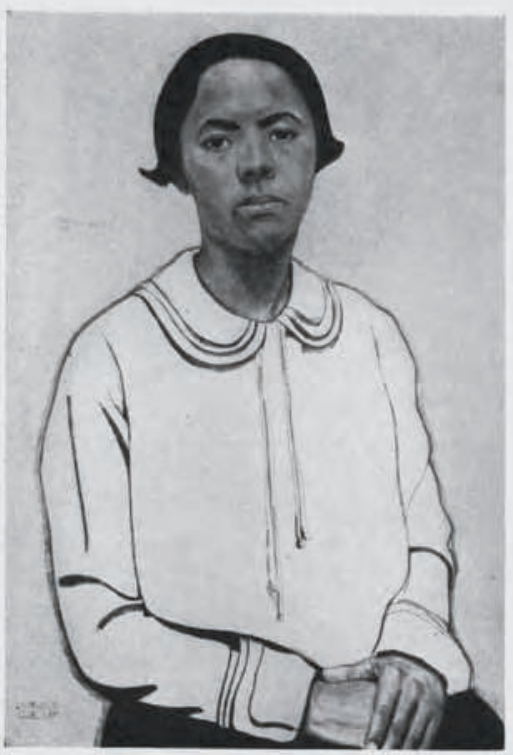

A woman lawyer

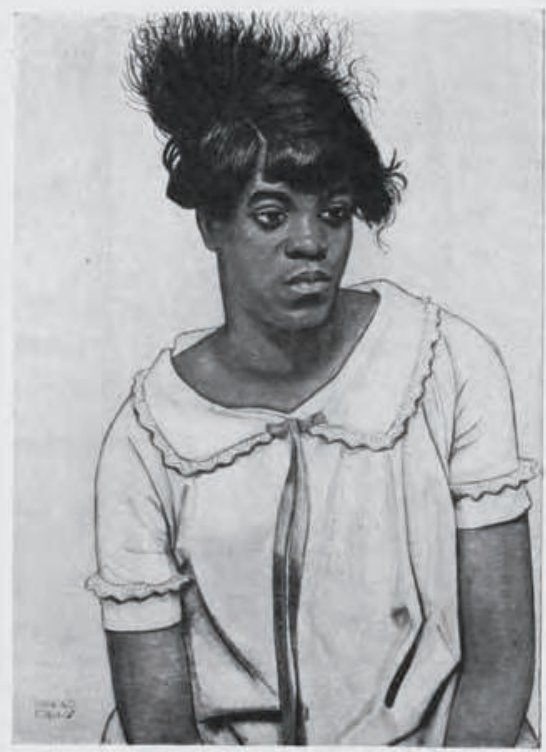

Girl in the white blouse

fig. 3

Winold Reiss, dessins

illustrant l'article non signé

"Harlem Mecca of the New

Negro ", in The Survey

(Graphic Number), LIII (11),

p.653. Courtesy of

The Reiss Partnership. 


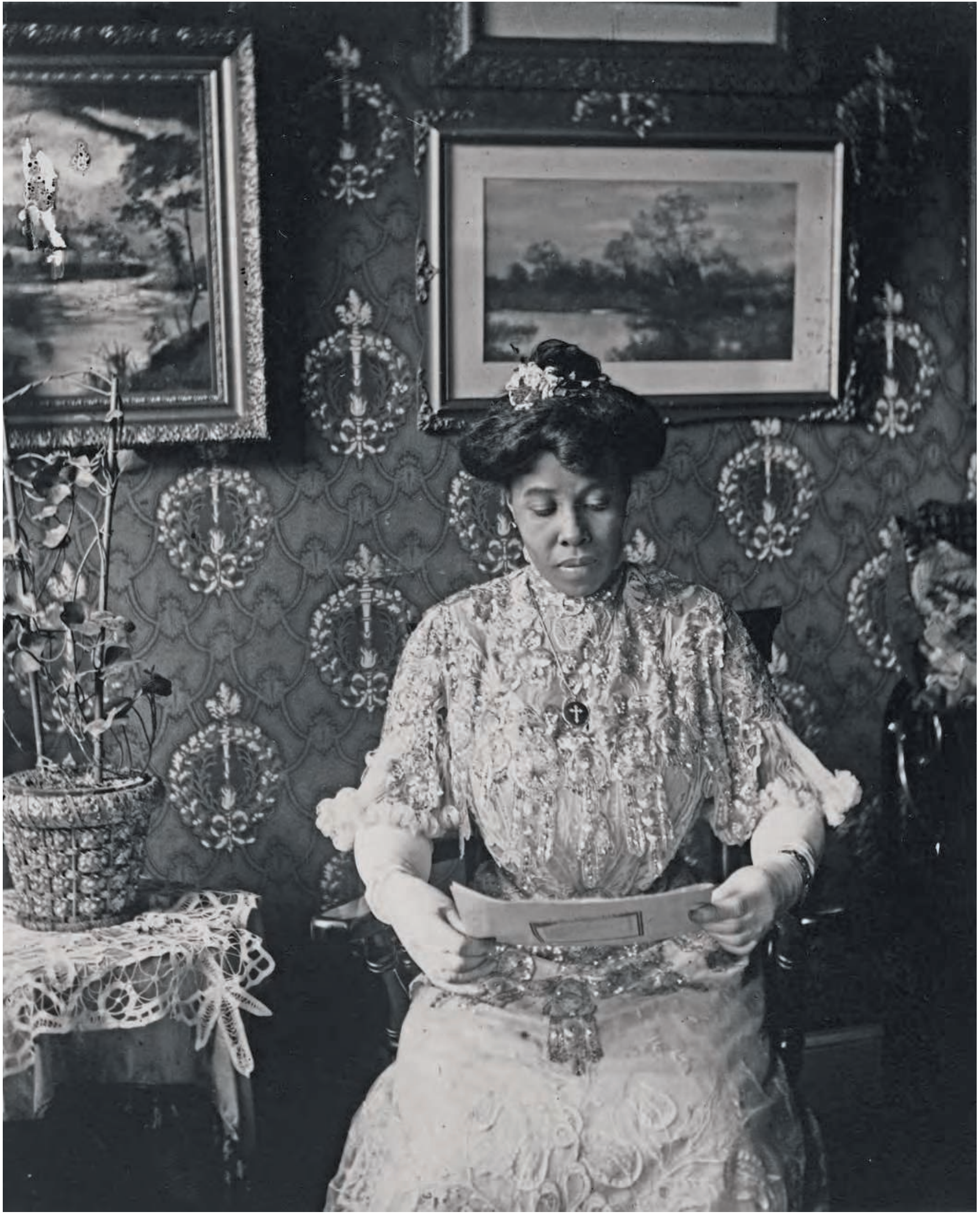


Malgré ces déclarations d'intention, les portraits reproduits, accompagnés la plupart du temps de légendes non nominatives et génériques, ont pour effet de réduire les Afro-Américains à des catégories connues du lecteur blanc ${ }^{22}$.

L'ensemble des points évoqués ci-dessus est emblématique des tensions et des positions souvent contradictoires liées à la représentation du nouveau Nègre qui émergent pendant la Renaissance de Harlem. Nombreux sont ceux qui ont critiqué l'élitisme de certains acteurs de ce courant. Cunard fustige à ce titre et à plusieurs reprises dans Negro la position de la «bourgeoisie noire», représentée notamment par le NAACP, qu'elle oppose à la défense communiste de l'Afro-Américain. Dans son ouvrage, l'absence de photographies de Carl Van Vechten ${ }^{\mathbf{2 3}}$, James L. Allen (pourtant recommandé avec enthousiasme auprès d'elle par Langston Hughes ${ }^{24}$ ) ou de James Van Der Zee, très couru dans les années 1920 et 1930, est en ce sens significative. Propriétaire d'un atelier de portraits sur Lennox Avenue, ce dernier réalise des photographies de la communauté afroaméricaine lors des mariages, enterrements ou défilés. Ignorant les habitants pauvres du quartier, ses portraits, comme le note Mary Schmidt Campbell, «sont identifiables aux quelques mises en scène composées avec attention, qui avaient pour but de représenter une vie bourgeoise bien rangée ${ }^{\mathbf{2 5}}$ ». Habillant ses modèles, leur faisant prendre la pose, il n'hésite pas à retoucher les images en faisant disparaître des rides, en ajoutant des cheveux, en blanchissant des dents ou une peau trop foncée, ou à enrichir ses mises en scène avec des accessoires, des bijoux par exemple (fig. 4). Ainsi, «[l]'image de la Renaissance de Harlem, capturée dans les photographies de Van Der Zee, était à la fois celle de la dignité et d'un artifice construit avec soin ${ }^{26}$ ».

À l'opposé de ces représentations pittoresques et «artificielles», Cunard privilégie une représentation réaliste de la "présence» afro-américaine: «Regardez combien de Blancs sont faux [unreal] en Amérique; ils sont ternes [dim]. Mais le Nègre est très vrai [real]; il est là ${ }^{\mathbf{2 7}}$. »

\section{Proximité du sujet et distance du regard : I'Afro-Américain et le documentaire engagé dans les années 1930}

«The new book on COLOR [...] will be entirely documentary, exclusive of romance or fiction ${ }^{28}$. » Nancy Cunard

\section{L'Afro-Américain dans la presse illustrée communiste: Cunard et la Workers' Film and Photo League (1930-1935)}

Dans Negro, cette quête de réalisme est particulièrement visible sur les photographies qui accompagnent les articles ayant trait au communisme. On y voit des portraits d'Afro-Américains notables comme James W. Ford, "chef de la Ligue de la défense des droits nègres et candidat communiste à l'élection du vice-président aux élections de novembre 1932 29 ", ou d'autres leaders et militants communistes comme B.D. Amis, David Poindexter, Charles Alexander, ainsi que quelques anonymes. Beaucoup sont photographiés en train de parler à la foule ou font directement face à l'opérateur (fig. 5). Illustrant l'entente entre les Blancs et les Afro-Américains prônée par les membres du parti communiste américain, on trouve un nombre important d'images les montrant ensemble, unis dans la défense des droits des travailleurs ou d'autres causes populaires. La construction
22. Le motif de la "mère à l'enfant » est particulièrement récurrent dans les représentations positives de l'Afro-Américaine. Locke choisit d'ailleurs d'ouvrir The New Negro avec une "madone noire " de Winold Reiss.

23. Nancy Cunard adopte dans son ouvrage une position très critique vis-àvis du portrait littéraire de la communauté de Harlem réalisé par Carl Van Vechten. Voir Cunard (éd.) 1934: 73. Ce point de vue est partagé par nombre d'artistes et intellectuels de l'époque, dont Claude McKay (voir dans ce numéro les extraits de lettres p. 196-201).

24. "James L. Allen, 213 West 121st. Street, N.Y., est probablement celui qui, dans le monde entier, sait le mieux photographier les Noirs [Negroes]... ». Lettre de Langston Hughes à Nancy Cunard datée du 3 septembre 1931, Nancy Cunard Collection, Harry Ransom Center, Université du Texas à Austin. Depuis le milieu des années 1920 les portraits d'Allen sont publiés dans des revues afro-américaines telles que Opportunity, The Messenger et The Crisis. Le photographe travaille aussi régulièrement à partir de cette période pour des agences publicitaires ; McKay inclut quelques-unes de ses images dans Harlem: Negro Metropolis (1940), Voir Holloway 1999: 11.
25. "His studio portraits are identifiable by a few carefully composed sets, which were meant to represent an orderly bourgeois life. " (Mary Schmidt Campbell, «Introduction », in Driskell et al. 1994 [1987]: 36 , notre traduction)

26. "The image of the Harlem Renaissance, captured by Van Der Zee's photographs, was partially real pride and partially carefully constructed artifice. " (Ibid., notre traduction)

27. Cunard (éd.) 1934: 69, souligné par Cunard.

28. "Le nouvel ouvrage sur la COULEUR [...] sera entièrement documentaire, sans romantisme ni fiction. " (Nancy Cunard, $1^{\text {er }}$ avril 1931 citée in Hugh Ford (éd.), Negro: An Anthology, "Introduction", 2002: XVII, notre traduction)

29. Cunard (éd.) 1934 : 280.

\section{ci-contre}

fig. 4

James Van Der Zee, Miss Suzie Porter, Harlem, 1915. Minneapolis Institute of Arts, MN, USA / The Bridgeman Art Library (C) James Van Der Zee Estate. 
30. La Workers' Film and Photo League (FPL) voit le jour à l'hiver 1930, suite à une association du Worker's Camera Club de New York avec I'International Labor Defense au printemps précédent, puis avec la WIR quelques mois plus tard. Voir Campbell 1984 71-72. Le «Workers' » est abandonné après 1933. Ibid. : 69. La FPL inclut des divisions à Los Angeles, Chicago, Philadelphie, Détroit, San Francisco, ainsi que dans d'autres petites villes comme Laredo (Texas). Voir Tucker 2011: 324

31. "[...] to aweken the working class, to support its political activities through meetings and boycotts, and to establish a film and photo school that would produce and exhibit politically committed photographs, newsreels, and films." (Barsam 1973: 146, notre traduction)
32. "The capitalists, on the contrary, exploit the use of photography to the limit as is evidenced in most advertising and in the press, which shown by the large circulation of the tabloids. There is no better example of the vicious distortion of news than the method practiced by the tabloids, where the news lines under the photos are distinctly different from the content of the picture. [...] It is urgent that the workers utilize photography to combat the vicious propaganda of the capitalist press. [...] A sense of authenticity exists in photos which cannot be duplicated by any other art. " (Ibid., notre traduction)

33. Ada Wright est la mère de Roy et d'Andrew (Andy) Wright, deux des neuf garçons accusés dans l'affaire de Scottsboro.

\section{ci-contre}

fig. 5

Photographie anonyme

illustrant I'article de Michael Gold, "A Word as to Uncle Tom », in Cunard (éd.) 1934, p. 235. même de certaines de ces images repose sur un parallélisme des corps en accord avec un principe d'égalité (fig. 6).

Pour la plupart, ces photos sont créditées «Workers' Film-Photo League, 16 W, 21 St., New York», «Workers' International Relief, 16 W, 21 St., New York» ou simplement «Workers' International Relief» (WIR). La (Worker's) Film and Photo League est fondée en 1930 à New York ${ }^{30}$. Elle est une branche de la Worker's International Relief (WIR), cellule américaine de I'Internationale Arbeiter-Hilfe (IAH), cette dernière créée à Berlin par Willi Münzenberg sous l'instigation de Lénine et du parti communiste en 1921. Si son but premier est de combattre la famine en Union soviétique, puis de soutenir matériellement les grévistes et leurs familles, les activités de l'IAH et de ses sections internationales s'étendent rapidement au terrain des médias. S'inspirant des actions de propagande menées par Münzenberg (notamment la création des revues AIZ et Der Arbeiter-Fotograf), la WIR développe ses activités de production, de réalisation et de diffusion de photographies comme de films traitant de l'Union soviétique et des grèves communistes ou qui dénoncent les conditions de vie des ouvriers (Campbell 1977). Les moyens engagés dans cette activité de propagande se renforcent pendant les années de la Grande Dépression, alors que les conditions de vie des ouvriers américains se détériorent. Les membres de la Workers' Film and Photo League (FPL) souhaitent « réveiller la classe ouvrière, soutenir ses activités politiques par des réunions et des boycotts, et [...] créer une école de cinéma et de photographie qui produirait et exposerait des photographies, des films d'actualité et des films engagés politiquement ${ }^{31}$ ». La FPL assume également un rôle d'agence en distribuant ses photographies dans les journaux et les magazines de la classe ouvrière ou dans d'autres publications de gauche, dont le Labor Defender, New Masses, The Daily Worker, Der Arbeiter-Fotograf, Freiheit, Labor Unity, Better Times Magazine, Fortune Magazine, Jewish Daily Bulletin ou The Survey. En tant qu'agence, la FPL assure la diffusion de leurs productions et représente une source de revenus à la fois pour l'association et pour les photographes (Ward 1934). Par leur fidélité au réel et donc à un rendu "authentique» des événements, leurs images visent à contrecarrer l'influence néfaste, sur l'ouvrier, des tabloïds "capitalistes» qui "détournent avec vice l'information ${ }^{32}$ ». Dans la lignée de I'IAH, les thèmes privilégiés par la FPL touchent à la vie des ouvriers et des plus démunis (enfance, éducation, santé, logement, travail) comme aux grèves ou aux manifestations mobilisant les communistes. Les photographes documentent également les luttes afro-américaines pour les droits civiques et les injustices liées à la ségrégation, comme en témoigne leur couverture de l'affaire des Scottsboro Boys, érigés en symboles vivants de l'oppression des Afro-Américains. L'article de Cunard sur cette affaire inclut un nombre important de photographies créditées «WIR" ou «FPL", notamment de manifestations ou d'Ada Wright en campagne pour leur libération ${ }^{33}$. Contrant les clichés avilissants ou idéalistes de la femme afro-américaine, ces images mettent en avant sa modernité et son indépendance: comme les communistes de Negro, elle est montrée en action, systématiquement de face, son regard interpellant le lecteur (fig.7).

Si une liste exhaustive des photographes membres de la FPL reste encore à établir, le récent intérêt pour la Photo League, créée en 1936 suite 


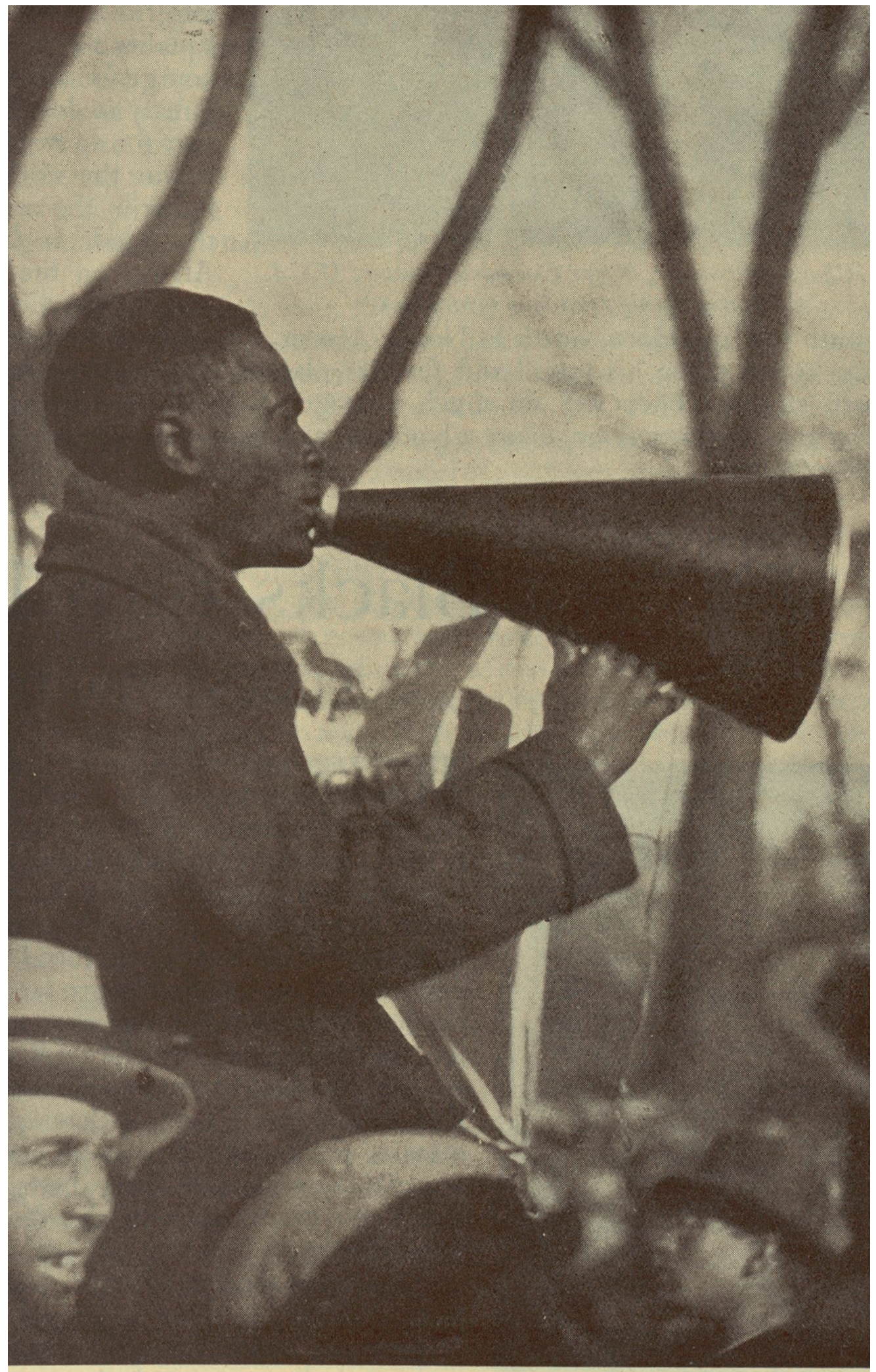

Poyndexter, Negro Communist, speaking opposite the White House, Washington Photo by Workers' Film-Photo League, 16 W. 21 st St., New York 


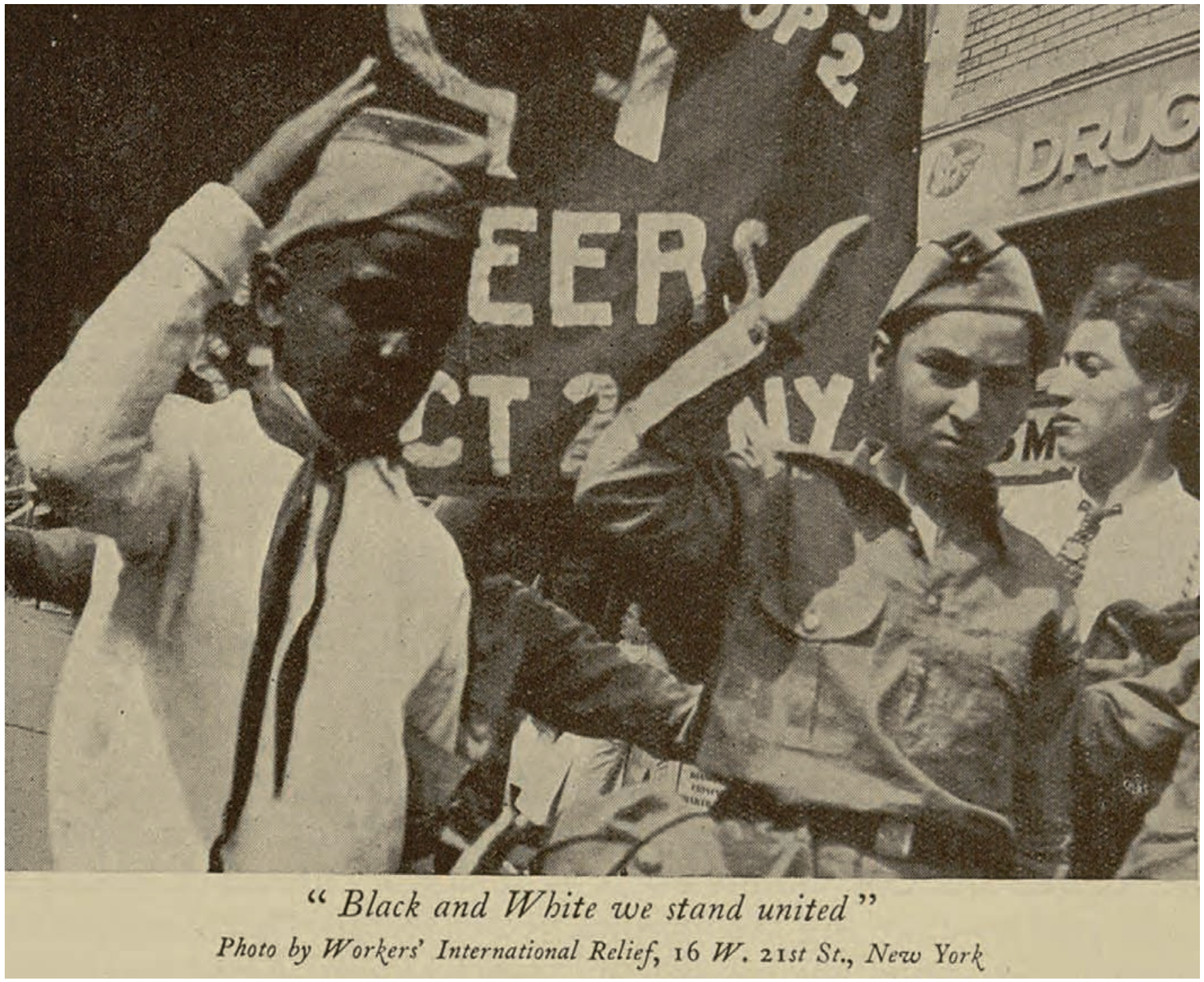

\section{ci-dessus}

fig. 6

Photographie anonyme

illustrant l'article non signé

"Afro-American Editor is for

Communists ", in Cunard

(éd.) 1934, p. 242. [Première

publication in The Liberator,

19 nov. 1932].

\section{ci-contre}

fig. 7

Photographie anonyme

illustrant l'article de Nancy

Cunard, "Scottsboro

- and other Scottsboros",

in Cunard (éd.) 1934, p. 257 


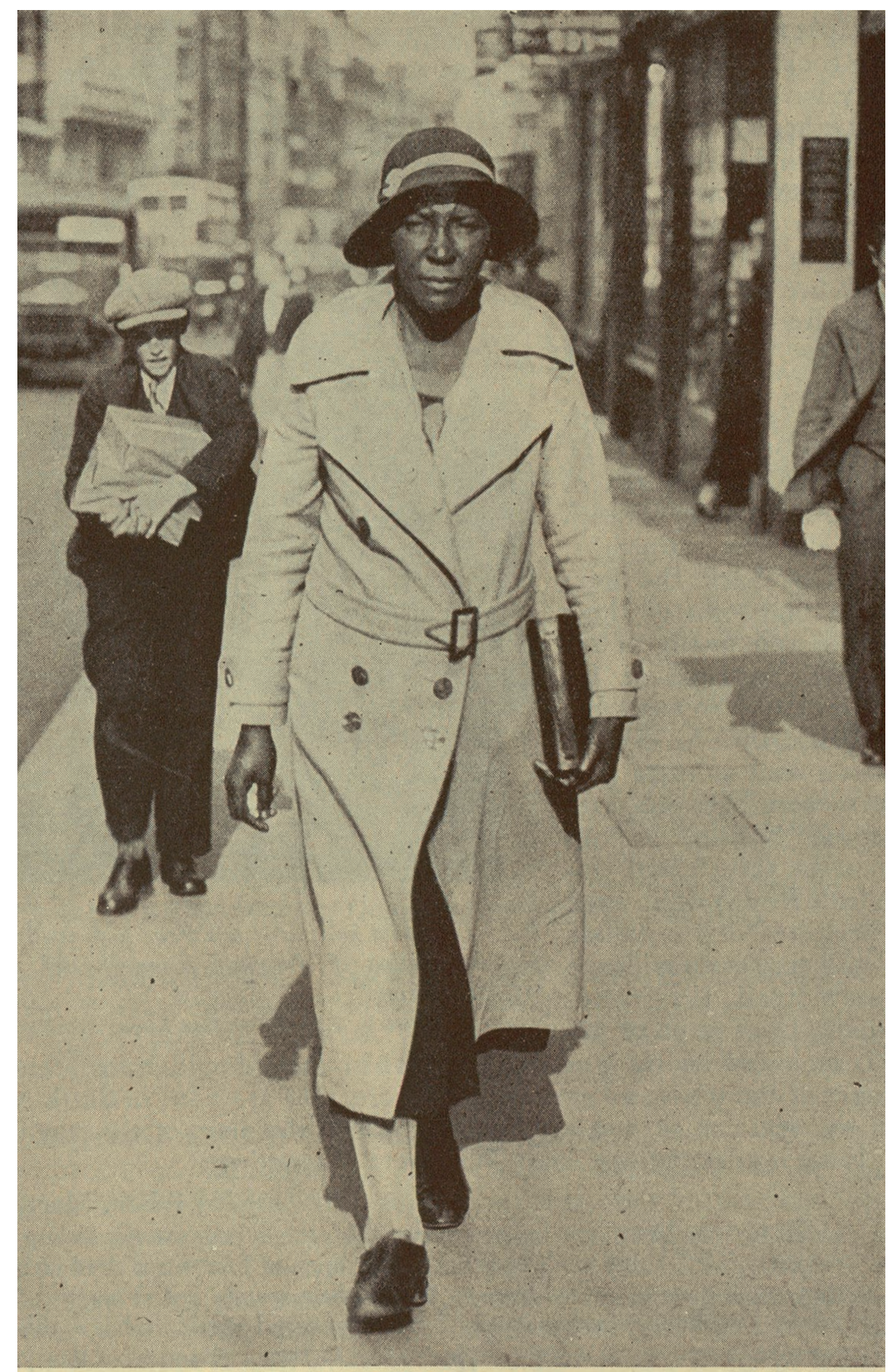

Ada Wright, mother of Roy and Andy Wright, two of the 9 innocent Scottsboro boys, walking down Fleet St. to interview newspaper editors in her campaign for the liberation of her sons and the 7 other lads. London, July 1932. 


\section{Harlem Reviewed}

of the black bourgeoisie all along the line, but nowhere as vilely so as in their newspapers. The Negro race in America has no worse enemy than its own press.

If treachery and lying are its main attributes so is snobbery flourishing in certain parts of Harlem. "Strivers Row"; that is what I 39 th Street has been called. An excellent covering-name for " those Astorperious Ethiopians," as one of their own wits put it. There are near-white cliques, mulatto groups, dark-skinned sets who will not invite each other to their houses; some would not let a white cross their thresholds. The Negro "blue-bloods" of Washington are famous for their social exclusivity, there are some in Harlem too. I don't know if a foreign white would get in there, possibly not. The snobbery around skin-colour is terrifying. The light-skins and browns look down on the black; by some, friendships with of ays are not tolerated, from an understandable but totally unsatisfactory reaction to the general national attitude of white to coloured on the social equality basis. A number of the younger writers are race-conscious in the wrong way, they make of this a sort of forced, self-conscious thing, give the feeling that they are looking for obstacles. All this, indeed, is Society with a vengeance! A bourgeois ideology with no horizon, no philosophical link with life. And out of all this, need it be said, such writers as Van Vechten and Co. have made a revolting and cheap lithograph, so that Harlem, to a large idle-minded public, has come to mean nothing more whatsoever than a round of hooch ${ }^{1}$-filled night-clubs after a round of "snow" 2-filled boudoirs. Van Vechten, the spirit of vulgarity, has depicted Harlem as a grimace. He would have written the same way about Montparnasse or Limehouse and Soho.

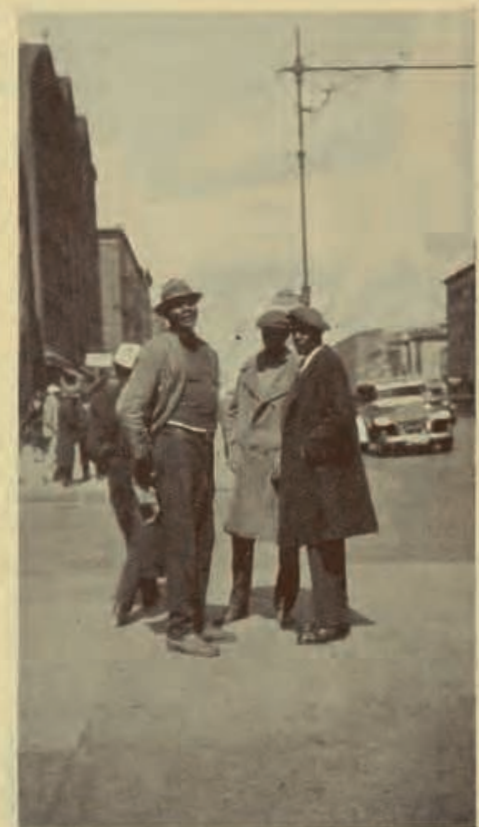

On the Corner 129th St. and $7^{\text {th }}$ Are. Harlem Do places exist, or is life itself as described by Paul Morand (another profiteer in coloured "stock")? Claude MacKay has done better. The studies in inter-colour relationships (in Ginger Town) are honest. But his people, and himself, have also that wrong kind of race-consciousness; they ring themselves in, they are umbrageous. The "Negro Renaissance" (the literary movement of about 1925 , now said to be at a halt, and one wonders on whose authority this is said) produced many books and poems filled with this bitter-sweet of Harlem's glitter and heart-break.

This is not the Harlem one sees. You don't see the Harlem of the romancists ; it is romantic in its own right. And it is hard and strong; its noise, heat, cold, cries and colours are so. And the nostalgia is violent too; the eternal radio seeping through everything day and night, indoors and out, becomes somehow the personification of restlessness, desire, brooding. And then the gorgeous roughness, the gargle of Louis Armstrong's voice breaks through. As everywhere, the real people are in the street. I mean those young men on the corner, and the people all sitting on the steps throughout the breathless, leaden summer. I mean the young men in Pelham Park; the sports groups (and one sees many in their bright sweaters), the strength of a race, its beauty. 1 Drink.

2 Cocain.

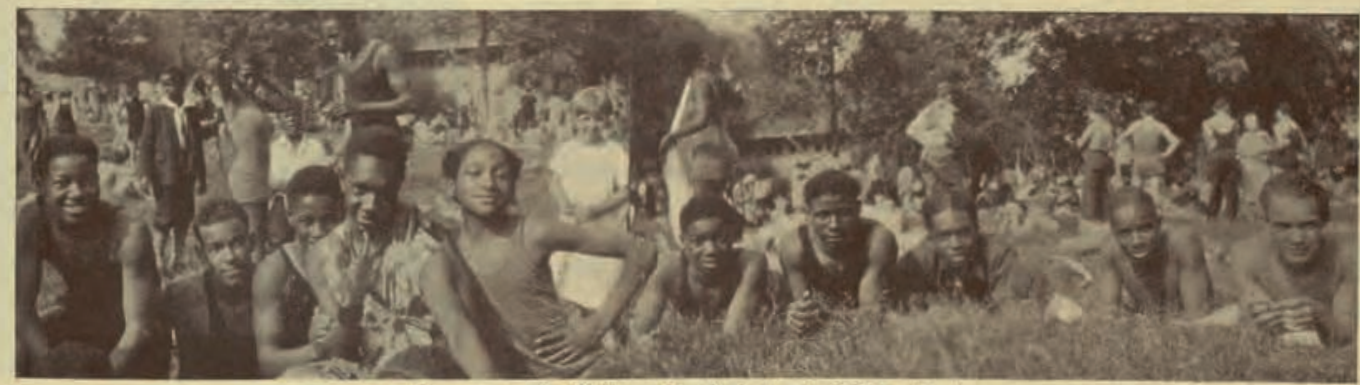

Young men in Pelham Park, just out of New. York 
à une reconfiguration de la FPL, a permis d'en identifier certains, dont Arnold Eagle, Aaron Siskind, Richard Lyon, ainsi que Sid Grossman et Sol Libsohn ${ }^{34}$. Retrouver les auteurs des photographies prises dans le cadre des projets de la FPL est néanmoins difficile: conformément à l'idéologie communiste, la notion d'auteur en est en effet volontairement effacée au profit de celle d'amateur et de réalisation collective. Rappelons aussi que le parti communiste américain et ses sympathisants subissent à l'époque d'importantes pressions; cet anonymat peut donc se comprendre également comme un moyen de protéger les membres de la FPL ${ }^{35}$. L'identité collective des productions fait assez rapidement l'objet de discussions parmi les membres de l'organisation qui, s'inscrivant dans un questionnement contemporain sur l'identité artistique de l'image photographique, remettent en question la légitimité de l'objectivité documentaire. Certains des réalisateurs souhaitent ainsi élargir leurs productions à la fiction; d'autres dénoncent une trop grande soumission aux besoins de la propagande (Raeburn 2006: 220). Ces dissensions aboutissent fin 1934 à la création de la coopérative militante Nykino ${ }^{36}$ par une partie des réalisateurs, et à celle de la Photo League en 1936 par certains des photographes ${ }^{37}$. Les discussions sur l'esthétisme de la photographie documentaire, entamées au sein de la FPL, se poursuivent chez les membres de la Photo League. Si la nature hybride des projets menés, entre engagement militant et recherche formelle, est chez ces derniers ouvertement assumée ${ }^{38}$, les quelques comptes rendus de réunions nous renseignent sur la difficulté de satisfaire ces deux enjeux, comme en témoigne notamment leur projet sur le quartier de Harlem (Raeburn 2006: 229-230).

\section{Pour un regard documentaire sur la communauté afro-américaine: I’anthologie Negro, la Photo League et le Harlem Document}

"So we may say that the vanguard photography of the present is documentary, by which we mean that it presents a well defined content, in a context of contemporaneous reality. " Elizabeth McCausland, «Documentary photography », manuscrit d'une conférence délivrée à la Photo League, New York, 27 juillet $1938^{39}$

Selon Cunard, la plupart des productions contemporaines ne refléteraient pas «le Harlem que les gens voient. On ne voit pas le Harlem des romantiques; le quartier est romantique en soi. Et il est dur et robuste [hard and strong]; son bruit, sa chaleur, sa froideur, ses cris et ses couleurs sont ainsi. Et la nostalgie est violente également; la radio pénètre tout, à chaque heure du jour et de la nuit [...]. Comme partout, les vraies gens sont dans la rue ${ }^{40}$. " Les images qu'elle choisit pour illustrer l'article «Harlem reviewed $\mathbf{4 1}$ » montrent en effet sa préférence pour des scènes en extérieur, depuis des groupes d'enfants jouant dans Pelham Park jusqu'à des gros plans de vendeurs de rue en passant par des vues d'ensemble surélevées de la ville (fig. 8). À rebours des représentations partielles et stéréotypées, Cunard défend ici une exhaustivité «documentaire», une image non spectaculaire de l'Afro-Américain «de la rue», simple et ordinaire, «vraie». Si aucune des photographies de son article n'est créditée «FPL», elles reflètent néanmoins des thématiques et des partis pris de représentation partagés par un grand nombre de membres de l'association comme par ceux qui poursuivent leur action au sein de la Photo League à partir de 1936:
34. Les archives et les films réalisés par la FPL permettent aujourd'hui d'établir une liste relativement exhaustive des membres de la branche cinématographique de l'organisation. Parmi les membres fondateurs, on compte les réalisateurs Sam Brody, Lester Balog, Robert Del Duca et Leo Seltzer. Ils sont bientôt rejoints par une centaine d'autres membres, dont Lewis Jacobs, Leo Hurwitz ou Ralph Steiner. On estime à environ quarante-cinq le nombre de photographes inscrits à la FPL en 1931. Voir Barsam 1973: 146, note 19.

35. La signature "collective» était déjà pratiquée par les membres de la WIR. Sur ce point, voir Ollman 1994 : 155.

36. La coopérative Nykino est active jusqu'en 1937, mais certains de ses membres rejoignent dès 1936 le groupe radical Frontier Group, actif jusqu'en 1942. Voir Barsam 1973: 147-148.

37. D'autres membres continuent à opérer sous la bannière de la New York Film and Photo League jusqu'à I'hiver 1937-1938. Voir Tucker 2011: 236

38. Beaucoup des photographies produites par l'organisation se retrouvent par ailleurs exposées rapidement sur les cimaises des musées, dont le Museum of Modern Art de New York.

\section{ci-contre}

fig. 8

Photographies anonymes illustrant l'article de Nancy Cunard, "Harlem Reviewed", in Cunard (éd.) 1934, p.73.
Cette tendance se renforce à la fin de la seconde guerre mondiale, alors que

l'organisation est mise sur la liste noire du procureur général Tom C. Clark, "qui [l'] incluait avec le parti communiste, le Ku Klux Klan, les vétérans de l'Abraham Lincoln Brigade, et quatrevingt-dix autres organisations et écoles, sur une liste de groupes totalitaires, fascistes, communistes et subversifs. " (Tucker 2011: 331, note 47 : "90 groups, schools names on U.S. list as being disloyal ", New York Times I [18], 5 décembre 1947)

39. "Nous pouvons donc dire que la photographie d'avant-garde contemporaine est documentaire, c'est-à-dire qu'elle expose un sujet bien défini, inscrit dans le contexte de la réalité contemporaine. " (cité in Tucker 2011: 341 , notre traduction)

40. "This is not the Harlem one sees. You don't see the Harlem of the romanticists; it is romantic in its own right. And it is hard and strong; its noise, heat, cold, cries and colours are so. And the nostalgia is violent too; the eternal radio seeping through everything day and night [...]. As everywhere, the real people are in the street. " (Cunard (éd.) 1934 : 73 , notre traduction)

41. Le verbe to review fait référence à l'expression française "passer en revue", dans une perspective de réexamination ou de réévaluation. 
42. La Photo League conserve également à partir de 1941 la collection photographique de Lewis $\mathrm{H}$. Hine, dont le dévouement à la cause ouvrière et la foi dans le pouvoir social et politique de la photographie documentaire s'affirment dès 1936 comme les modèles à suivre pour les membres de l'association. Sur l'importance du modèle de Hine pour les membres de la Photo League, voir Raeburn 2006: 226-228.

43. "[The Photo League] encourages instead

"features", related pictures that explored in depth broader social conditions, particularly in distinct neighborhoods where they would cover interrelationships among people, buildings, institutions, and social activities. Such photographs, in their view, did not require a text to be effective vehicles for cultural communication. ” (Ibid., notre traduction)

44. Sur les liens de la FPL et de certains membres de la Photo League avec la presse communiste américaine et européenne, voir ibid. : 242-245 et Dejardin 1994 : 159-173.

45. "Rosenblum described League members's work as photographying "our own flesh and blood". "We're not, he added, tourists spying on the quaint mannerisms of the people." (Walter Rosenblum, Photo Notes, janvier 1948 p. 7 , cité in Ollman 1994: 157, notre traduction)
46. Portrait of a Tenement (1936) ; The Catholic Worker Movement: St. Joseph House (1939-1940); Dead End: The Bowery (1937); Harlem Document (1937-1938); Park Avenue North and South (1938). Voir Van Arragon 2006: 245.

47. Le projet se poursuit sous une forme différente jusqu'en 1940. Certaines des photographies généralement rattachées au Harlem Document proviennent en réalité d'un projet annexe. Intitulé «Most crowded block", ce dernier est issu d'une collaboration entre Siskind, Max Yavno et Michael Carter en 1939-1940. Voir Siskind, Parks et Battle 1991 [1981] : 6.

48. Siskind publie en 1981 un ouvrage (réédité en 1991) avec ses photographies de Harlem, accompagné d'un texte du photographe et écrivain afro-américain Roy de Carava. les photographies des uns et des autres témoignent toutes d'une réflexion sur le juste équilibre entre objectivité et subjectivité face au sujet, ainsi que sur le respect de la bonne distance du regard blanc porté sur la communauté noire.

La Photo League regroupe de jeunes photographes blancs, amateurs ou professionnels, vivant dans les quartiers populaires de la ville (Lower East Side, Brooklyn, Bronx). Jusqu'à sa disparition en 1951, elle compte un nombre important de membres et de soutiens influents: dans son comité d'administration, on trouve ainsi la critique Elizabeth McCausland, les photographes Berenice Abbott, Paul Strand et Margaret Bourke-White; parmi les membres importants de l'organisation, citons ses cofondateurs Grossman et Libsohn, ainsi que Walter Rosenblum, Max Yavno, Morris Engel et Siskind. La Photo League crée une école de photographie, et donne en outre à ses membres accès à des laboratoires de développement et de tirage; ceux-ci organisent des expositions et financent des conférences, publient une newsletter et une revue (Photo Notes ${ }^{\mathbf{4 2}}$ ). S'éloignant des contraintes de la photographie journalistique et de son diktat du rendu de l'événement, la Photo League produit des enquêtes de fond. Comme l'analyse I'historien Joseph Raeburn, ce sont les «interrelations entre les personnes, les logements, les institutions et les activités sociales» qui sont particulièrement mises sous la loupe des photographes (Raeburn 2006: 220). Ces derniers privilégient la série d'images car ils pensent qu'elles peuvent, indépendamment de leur association avec le texte, être «des vecteurs efficaces pour la communication culturelle $\mathbf{4 3}^{\mathbf{4}}$. Si la Photo League n'est plus, comme la FPL, officiellement affiliée au communisme, ses membres continuent de défendre une pratique engagée de la photographie: dénonçant la pauvreté, les conditions de travail ou de logement, le manque de structures éducatives ou les discriminations, ils cherchent, par la force de leurs images, à susciter des réformes sociales $\mathbf{4 4}$. Leur implication personnelle traduit également leur responsabilité politique: comme l'explique Rosenblum, il s'agissait de photographier «notre propre sang et notre propre chair. [...] Nous ne sommes pas des touristes épiant les manies pittoresques des gens ${ }^{45}$.»

Membre de la FPL depuis 1932, puis de la Photo League dès 1936, Siskind met en place cette même année le Feature Group. Actif jusqu'en 1940, celui-ci rassemble les photographes Lucy Ashjian, Harold Corsini, Engel, Beatrice Kosofsky, Lyon, Jack (Mendelsohn) Manning, Miller Simon et Sol Prom (Solomon Fabricant) autour de la réalisation d'enquêtes photographiques informant sur les inégalités entre les classes riches et pauvres de la ville, comme celles dont pâtissent les populations «non blanches » et en particulier afro-américaines ${ }^{\mathbf{4 6}}$. Le projet le plus important, en termes de durée d'existence et de répercussion, est le Harlem Document qui occupe les membres du Feature Group au moins depuis le début de l'année 1938 jusqu'à la fin de 1939. Initié par l'écrivain et sociologue afro-américain Michael Carter, ce projet est piloté par Siskind, qui photographie Harlem dès $1932^{47}$. La majorité des archives du groupe ayant été dispersée et le manuscrit de Carter (réalisé en vue d'une publication illustrée) jamais retrouvé, les analyses de ce projet reposent essentiellement sur les comptes rendus des réunions du groupe, les photographies, les articles où elles ont été publiées, ainsi que sur les documents relatifs à leurs expositions de l'époque ${ }^{48}$. Trois d'entre elles ont lieu à Harlem: financée par la National 
Urban League, Toward a Harlem Document ouvre ses portes en février 1939 à la Young Men's Christian Association (YMCA) sur la 135e rue, puis le mois suivant à la Harlem Branch Library; la librairie Blyden l'accueille en mai 194049. Simultanément, les images sont maintes fois publiées dans des magazines populaires illustrés tels que, pour la période 1937-1941, Look, Fortune, The New Masses et U.S. Camera.

Comme le montre l'historienne Elizabeth Van Arragon dans son analyse du projet, «[I]a relation entre les sujets sociopolitiques et les préoccupations formelles était particulièrement pertinente pour l'élaboration d'un portrait de Harlem, qui était, depuis des décennies, le lieu des imaginations blanches et noires de la culture afro-américaine ${ }^{\mathbf{5 0}}$ ». Les membres du Feature Group ont conscience de cet état de fait, comme en témoigne notamment la déclaration de Carter publiée dans la brochure de la première exposition du Harlem Document: il y dénonce l'élitisme et la partialité de certains des écrivains de la Renaissance de Harlem comme l'exploitation de l'«exotisme» par d'autres auteurs. Ainsi, «dans la hâte généralisée de visiter les "coins chauds" de Harlem, le Nègre vrai et ordinaire et ses nombreux problèmes ont été négligés 51 ». Selon Van Arragon, le fait que le Feature Group travaille avec la National Urban League (NUL) confirme qu'il adhère à l'idée d'une responsabilisation politique des habitants de Harlem (Van Arragon 2006 : 257). Créée en 1910, la NUL agit en faveur des populations afro-américaines de New York: ses membres dirigent des actions dans les domaines du logement, du travail et de l'éducation; ils aident par ailleurs à la création et au développement de l'autonomie commerciale de la communauté. La structure de l'organisation et le projet du Feature Group ont plusieurs points communs: depuis sa création, la NUL compte parmi ses rangs des personnalités «blanches " et encourage la collaboration des communautés. On peut dès lors supposer qu'elle voit d'un bon œil le projet de collaboration entre Siskind et Carter $\mathbf{5 2}$. L'association avec la NUL a de plus permis au Feature Group d'«entrer dans des espaces privés tels que des églises, des appartements, et dans d'autres organisations communautaires ${ }^{53}$ ". Les longues recherches précédant la réalisation des photographies ont été rendues possibles car la NUL « récoltait des informations et des statistiques au moyen d'enquêtes, d'entretiens, et autres stratégies de recherche » avant d'organiser ses actions sociales ${ }^{54}$. Autre témoignage de la volonté des membres du Feature Group de travailler pour et avec les habitants de Harlem: les expositions organisées dans les centres communautaires de ce quartier étaient accompagnées d'un livre d'or visant à recueillir les encouragements mais également les critiques des premiers concernés 55 .

Si ces partis pris traduisent, chez Cunard comme au sein du Feature Group, un réel engagement en faveur de la communauté afro-américaine, ils ne sauraient néanmoins cacher un certain malaise lié à la production d'un discours blanc sur la communauté noire. Dans «Harlem reviewed », alors que Cunard se positionne clairement du côté des «artistes, des écrivains, des musiciens, des intellectuels [...] qui ont de bons amis parmi [les gens] de couleur, et une bonne connaissance de la vie de Harlem ", elle rappelle aussi que «[le] désir de se rapprocher de l'autre race n'a souvent rien d'honnête ${ }^{\mathbf{5 6}}$ ». Cette tension apparaît particulièrement dans la relation $\mathrm{du}$ texte aux images: sa prose, qui traduit son souci de description objective
49. Une autre exposition est organisée à la New School for Social Research (mai 1939), puis à la Photo League (juin 1939); l'exposition de la librairie Blyden est financée par le magazine Look, qui publie ce même mois un article de Carter illustré de photographies issues du Harlem Document. Lors de l'exposition The Pageant of Photography, organisée à l'occasion de la Golden Gate International Exposition de l'été 1940 à San Francisco, le photographe Ansel Adams présente quarante images du Harlem Document ainsi que cinquante autres clichés des membres de la Photo League. Voir Van Arragon 2006 : 256.

50. "The relationship between socio-political issues and formal concerns was particularly relevant to the portrayal of Harlem, a location that was the site of both black and white imaginings of African American culture for decades. " (Ibid. : 249, notre traduction)

51. "In the general rush to visit Harlem "hot spots" the real work-a-day Negro and his numerous problems were overlooked. " (Michael Carter cité dans Tom Fredrickson (éd.), This Was the Photo League: Compassion and the Camera from the Depression to the Cold Ward, Chicago, Stephen Daiter Gallery, 2001, p. 36, cité in ibid. : 250, notre traduction)

52. Celui-ci insiste luimême, dans une brochure accompagnant la première exposition du Harlem Document, sur les bienfaits de la collaboration entre ces deux communautés: "Sociologue et photographe, Nègre et Blanc, [Carter et Siskind] ont travaillé ensemble afin de concevoir le projet et ont partagé plusieurs et diverses tâches ", dans "une harmonie étroite", apprenant l'un de l'autre. ["Sociologist and photographer, Negro and White, have together designed the plan and have shared in the many and diverse labors. Working so far more than a year in the closest harmony, and with the frankest exchange of attitude and idea [...] "] (Ibid. : 250-251, notre traduction)

53. "That Feature Group members were able to enter private spaces like churches, apartments, and other community organizations in Harlem is explained by their connections to the National Urban League. " (Ibid. : 258 , notre traduction)

54. "[The National Urban League] assumed that the gathering of information and statistics through surveys, interviews and other research strategies, had to precede effective social action. " (Ibid., notre traduction)

55. Outre cette proximité du Feature Group avec la NUL, l'inscription politique du Harlem Document se remarque également par sa proximité avec les idéaux communistes. Mentionnons qu'à l'occasion de l'exposition organisée dans les locaux de la Photo League, Siskind et Carter organisent un symposium incluant des personnalités politiques de la communauté afroaméricaine, dont le chef de file communiste James W. Ford. Ibid. : 258-259.

56. "This desire to get close to the other race has often nothing honest about it [...]. »; "There are, however, thousands of artists, writers, musicians, intellectuals, etc. who have good friends in the darker race, and a good knowledge of Harlem life, "the freedom of Harlem", so to speak. " (Cunard (éd.) 1934: 69-70, notre traduction) 


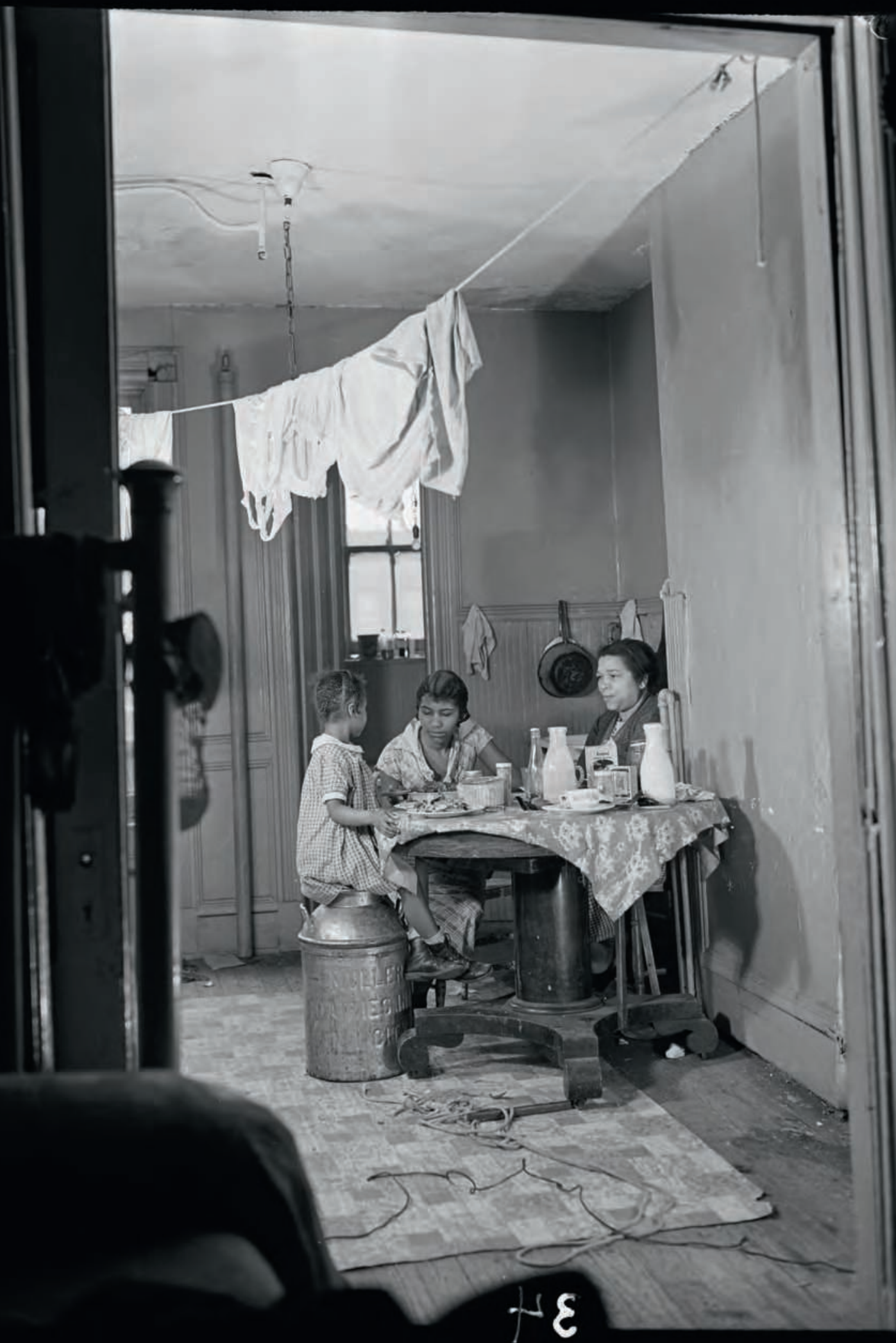


et exhaustive, révèle en même temps sa propre fascination; cet enthousiasme, pouvant être assimilé au regard objectivant du «Blanc » sur le «Noir» qu'elle dénonce dans ce même article, est tempéré par l'austérité des illustrations qu'elle choisit. L'exemple le plus probant reste son récit d'une réunion de réveil [revival meeting], dont elle cherche à retranscrire la ferveur par ces mots: «[...] il est impossible de transmettre la mesure de ces immenses vagues de son et de ces déferlements rythmiques. On est complètement transporté. [...] "S Suite à sa longue description du service religieux, elle dit donner autant de détails car cette réunion est «si fantastique, et, esthétiquement parlant, si émouvante ${ }^{57}$ ». En regard de ces mots, elle choisit de reproduire un simple portrait du pasteur Elder Becton, dont le classicisme contraste fortement avec la «chaleur » des propos qu'elle rapporte.

Les images produites par les membres du Feature Group sont également emblématiques d'une réflexion sur la juste distance du photographe à son sujet. Commentant la méthode de travail adoptée par le groupe, Siskind rappelle que, malgré l'importance des recherches et des entretiens préparatoires, il conseillait fortement à ses collègues «de devenir aussi passifs que possible face au sujet, d'oublier alors tout ce qu'ils savaient sur lui, de laisser les faits s'effacer et à ce moment crucial de lui permettre de parler pour lui-même et à sa façon $\mathbf{5 8}^{\mathbf{}}$. Comme dans Negro, certaines des images du Harlem Document contrent les stéréotypes de la représentation par des prises de vue frontales dans lesquelles les sujets affirment leur présence et leur individualité (fig. 10). D'autres sont réalisées au moyen de cadrages plus larges: elles créent ainsi une distance qui permet d'insister sur les rôles sociaux des habitants, sur leur place dans la communauté plutôt que de tomber dans le piège de la victimisation et du symbolisme «noirs " (Van Arragon 2006: 261). Cette distance permet également, chez Siskind en particulier, d'élaborer une réflexion plus large sur la représentation et le regard. Si ses images semblent souvent posées et célébrer les stéréotypes de la scène familiale ou de la ferveur religieuse, le cadrage large permet d'inclure des références au contexte de la prise de vue (fig. 9), par exemple des regards accusateurs, comme pour dénoncer le «cliché». Comme l'analyse I'historien Joseph B. Entin, ces clichés renvoient ainsi «subtilement, mais avec provocation [...] au malaise du regard entre classes et races différentes ${ }^{\mathbf{5 9}}$ ». Les photographies que Siskind fait dans un cabaret sont également exemplaires: prises en plongée, elles introduisent la thématique du voyeurisme, de «l'érotisation et de la marchandisation des corps noirs ", non seulement du point de vue du public «blanc», mais également de celui du photographe et plus généralement du projet du Harlem Document lui-même ${ }^{60}$.

Il est impossible de savoir jusqu'à quel point la complexité des images produites par le Feature Group a été pensée et contrôlée par leurs auteurs, et a fortiori comment celles-ci ont pu être comprises par le public. La question de leur réception est d'autant plus problématique que les journaux qui les publient dans les années 1930 et au début des années 1940 dirigent leur sélection et leur montage: en opposition à l'exhaustivité et à la contextualisation prônées par le Feature Group - réalisées par Cunard dans Negro -, les éditeurs de ces publications privilégient les aspects les plus négatifs de la vie de Harlem en se focalisant sur les problèmes de logement, de travail ou d'éducation des enfants. Dans ce sens, ils s'autorisent des
57. " [...] it is impossible to convey the scale of these immense sound-waves and rhythmical under-surges. One is transported, completely. [...] I have given all this detail about the revivalist meeting because it is so fantastic, and, aesthetically speaking, so moving. " (Ibid., p. 70-71, notre traduction)

58. "However, I cautionned my co-workers on this job to become as passive as possible when they faced the subject, to de-energize for the moment their knowledge of the ideas about the subject, to let the facts fall away and at that crucial moment to permit the subject to speak for itself and in its own way. " (Aaron Siskind, "The Drama of Objects " [1945], cité in Siskind, Parks et Battle 1991 [1981] : 5-6, notre traduction, nous soulignons)

59. "Siskind's images subtly but provocatively call attention to the uneasiness of the cross-class and interracial looking that his photographs of Harlem entails. " (Entin 1999: 358, notre traduction).

60. "Like many of Siskind's other photographs, these images thematize the politics of white looking, implying that white visual pleasure is frequently achieved through the erotization and commodification of black bodies. " (Ibid. : 373, notre traduction)

\section{ci-contre}

fig. 9

Aaron Siskind, Sans titre, ca. 1936-1940. Courtesy of George Eastman House, International Museum of Photography and Film (C) Aaron Siskind Estate. 


\section{ci-contre}

fig. 10

Lucy Ashjian, sans titre,

ca. 1935-1943 @ Lucy Ashjian

Estate, Collection Center

for Creative Photography,

The University of Arizona. 


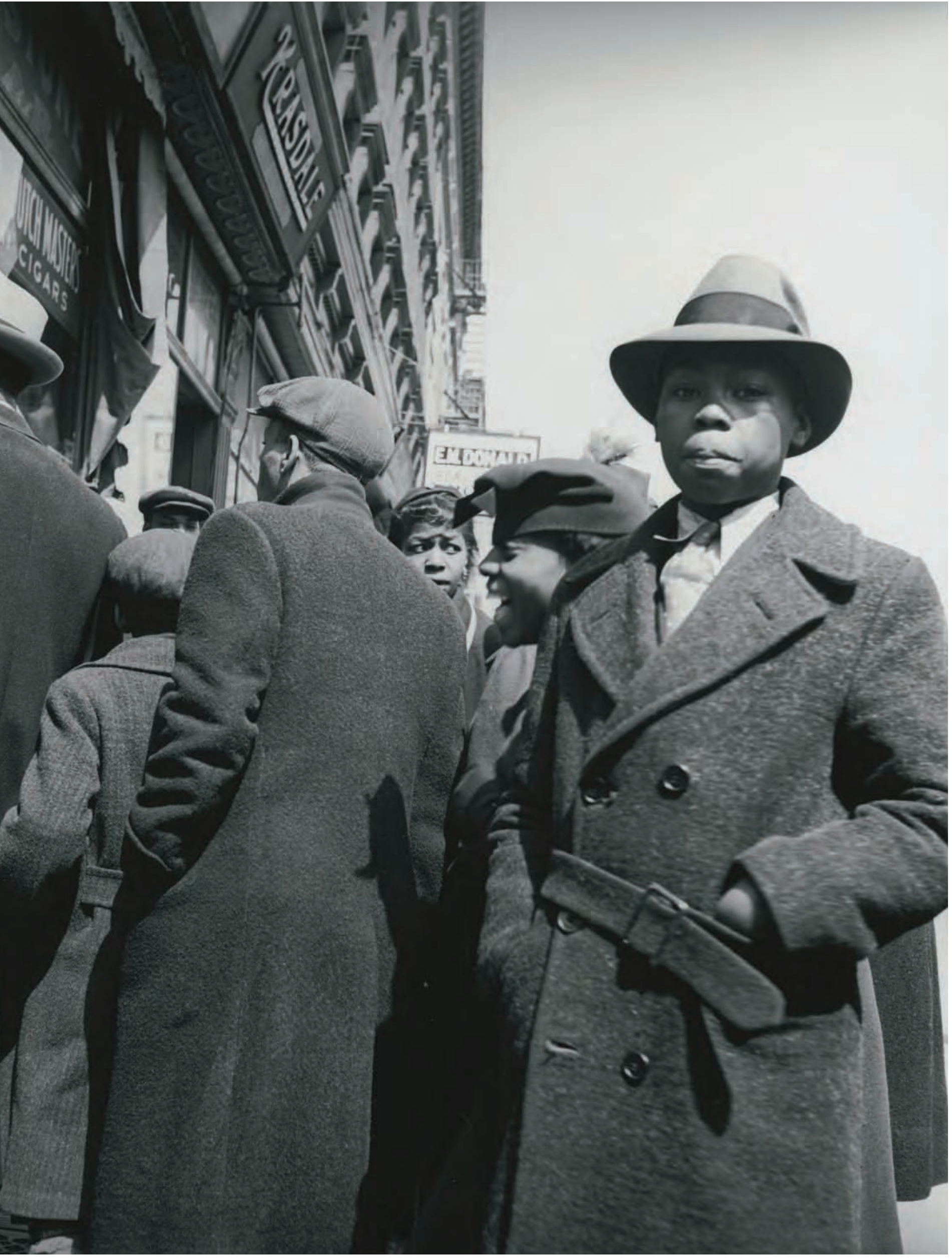


61. La Resettlement Administration (RA) est fondée en 1935 afin de subvenir aux besoins des fermiers, notamment en matière de logement, pendant la Grande

Dépression. Une section photographique est créée à cette date afin de produire des documents visuels sur leurs conditions de vie et de travail. Dirigée par Roy Stryker, elle est active jusqu'en 1942. La RA fusionne en 1937 avec la Farm Security Administration (FSA) mise en place par le ministère de l'Agriculture américain.

62. «[...] you [...] think you know us, but our history is far stranger than you suspect, and we are not what we may seem. " Wright et Rosskam 1941: 10, notre traduction, nous soulignons)

63. "Textually, 12 Million Black Voices raged and roared [...]. Pictorially, the dominant accent was one of muckracking. " (Natanson 1992 : 247, notre traduction)

64. "Throughout the book, Rosskam's manipulations were also crucial, with old tricks involving captioning and visual-textual juxtaposition turned to new purposes. " (Ibid. : 250, notre traduction)

\section{ci-contre}

fig. 11

Walker Evans, Flood refugees at mealtime, Forrest City,

Arkansas, février 1937, couverture de 12 Black Million Voices: A Folk History of the Negro in the United States, New York, Viking Press, 1941. Library of Congress, Prints \& Photographs Division, FSA/OWI Collection [LC-USF331-009231-M1]. recadrages drastiques qui tendent à effacer les subtilités des images de départ afin d'appuyer le sensationnalisme du sujet.

\section{Conclusion: la fin de l'utopie documentaire?}

En 1941, l'auteur afro-américain Richard Wright publie 12 Million Black Voices: A Folk History of the Negro in the United States, un ouvrage mêlant texte et photographies, à partir d'une étude qu'il consacre à l'histoire de l'Afro-Américain depuis les premiers temps de l'esclavage jusqu'à la période contemporaine (fig. 11). Les photographies sont issues d'une sélection d'images produites dans le cadre des projets de la section photographique de la Farm Security Administration ${ }^{61}$ (FSA); cette sélection est faite par Edwin Rosskam, ancien membre de la Photo League et iconographe de la FSA au moment de la réalisation de l'ouvrage. Si le livre semble à première vue partager l'approche de Cunard et des membres de la Photo League quant à la nécessité de rétablir un regard réaliste sur l'Afro-Américain, il s'y oppose sur plusieurs points.

Comme eux, Wright insiste sur la «parole» donnée à l'Afro-Américain: en témoigne son titre, mais également son choix d'utiliser le «nous » dans son texte qui, outre qu'il marque l'engagement de son auteur, fait littéralement «parler» les personnes représentées sur les photographies. II entreprend également de longues recherches afin de respecter une approche scientifique de son sujet. II fait également une distinction très claire entre la bourgeoisie afro-américaine et le reste de la communauté, en expliquant en introduction qu'il ne traitera pas des classes les plus favorisées afin de se concentrer sur la description du phénomène complexe d'avilissement du «Noir» populaire, depuis sa réduction en esclavage jusqu'à la place qu'il occupe dans la société urbanisée du $x x^{e}$ siècle. Enfin, les photographies choisies par Rosskam, comme le texte de Wright, proposent une réflexion sur la représentation de l'Afro-Américain quand, dès le début du premier chapitre, Wright interpelle le lecteur par ces mots: "Vous pensez habituellement que vous nous connaissez, mais notre histoire est bien plus étrange que vous ne le suspectez, et nous ne sommes pas ce que nous paraissons ${ }^{62}$."

Malgré ces nombreux points communs, 12 Million Black Voices se distingue fortement des propositions précédentes par sa rhétorique sensationnaliste: loin de la pudeur des illustrations de Negro ou des images de la Photo League, il s'agit ici clairement de faire réagir le lecteur face à une situation d'urgence. Selon l'historien Nicholas Natanson : «Le texte de $12 \mathrm{Mil}-$ lion Black Voices hurlait et rugissait [...]. L'accent dominant des images était celui du scandale ${ }^{63}$. " Les stéréotypes sont attaqués de front dès le début de l'ouvrage par une série d'images légendées simplement: «la servante noire", "l'ouvrier noir», "le docker noir», «la danseuse noire», «le serveur noir», «le métayer noir » (Natanson 1992: 18-23). De plus, de nombreuses photographies y abordent sans retenue les inégalités et les violences subies, comme celles montrant des logements surpeuplés et délabrés ou des scènes de lynchage. Enfin, «les manipulations de Rosskam étaient déterminantes»; il n'a pas hésité à utiliser «les vieilles astuces par lesquelles les légendes et les juxtapositions texte/image créent de nouveaux sens ${ }^{64}$ ". Rejetant définitivement le réalisme documentaire des années 1930, Rosskam a retouché les images afin qu'elles correspondent davantage au discours (ibid.: 251-253); 


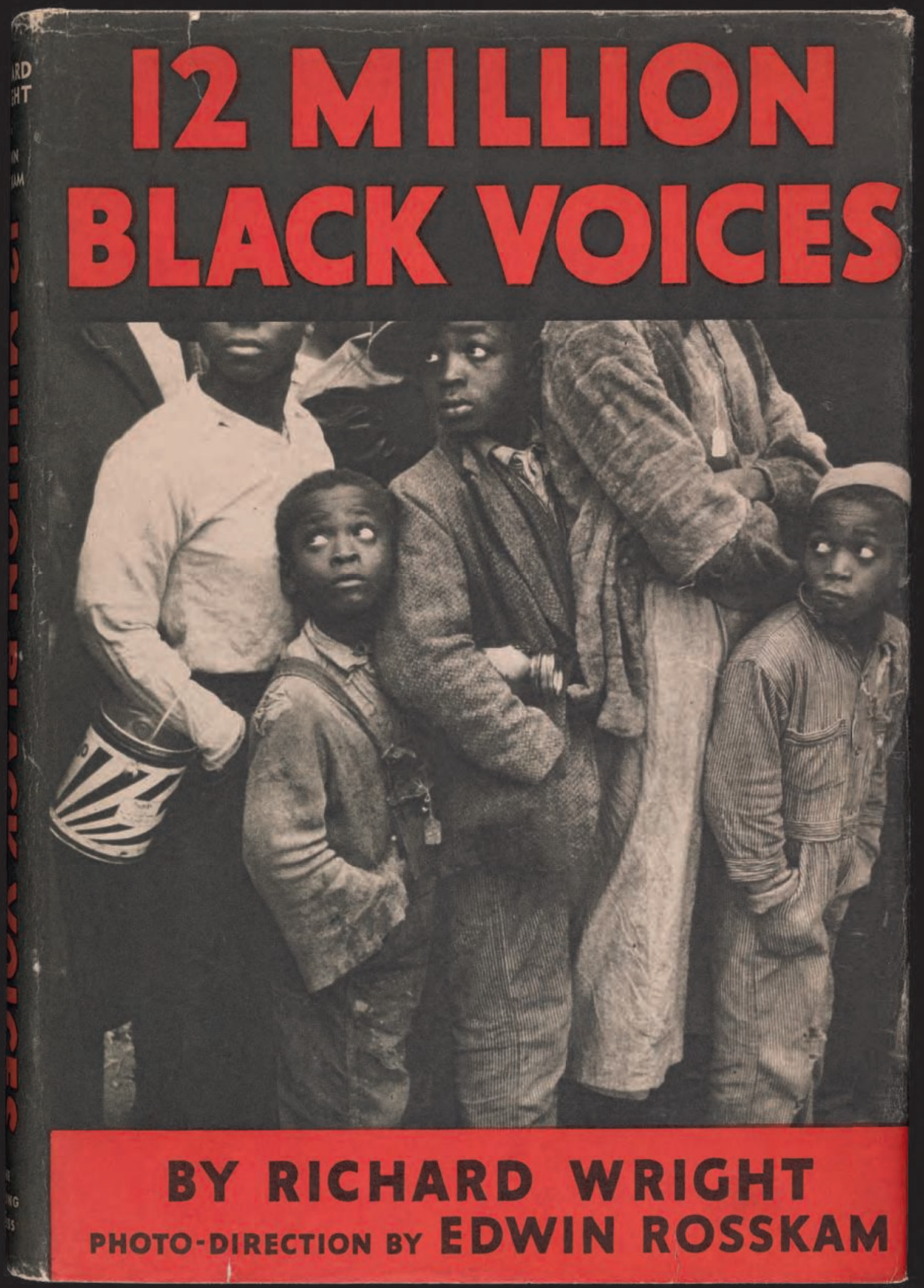




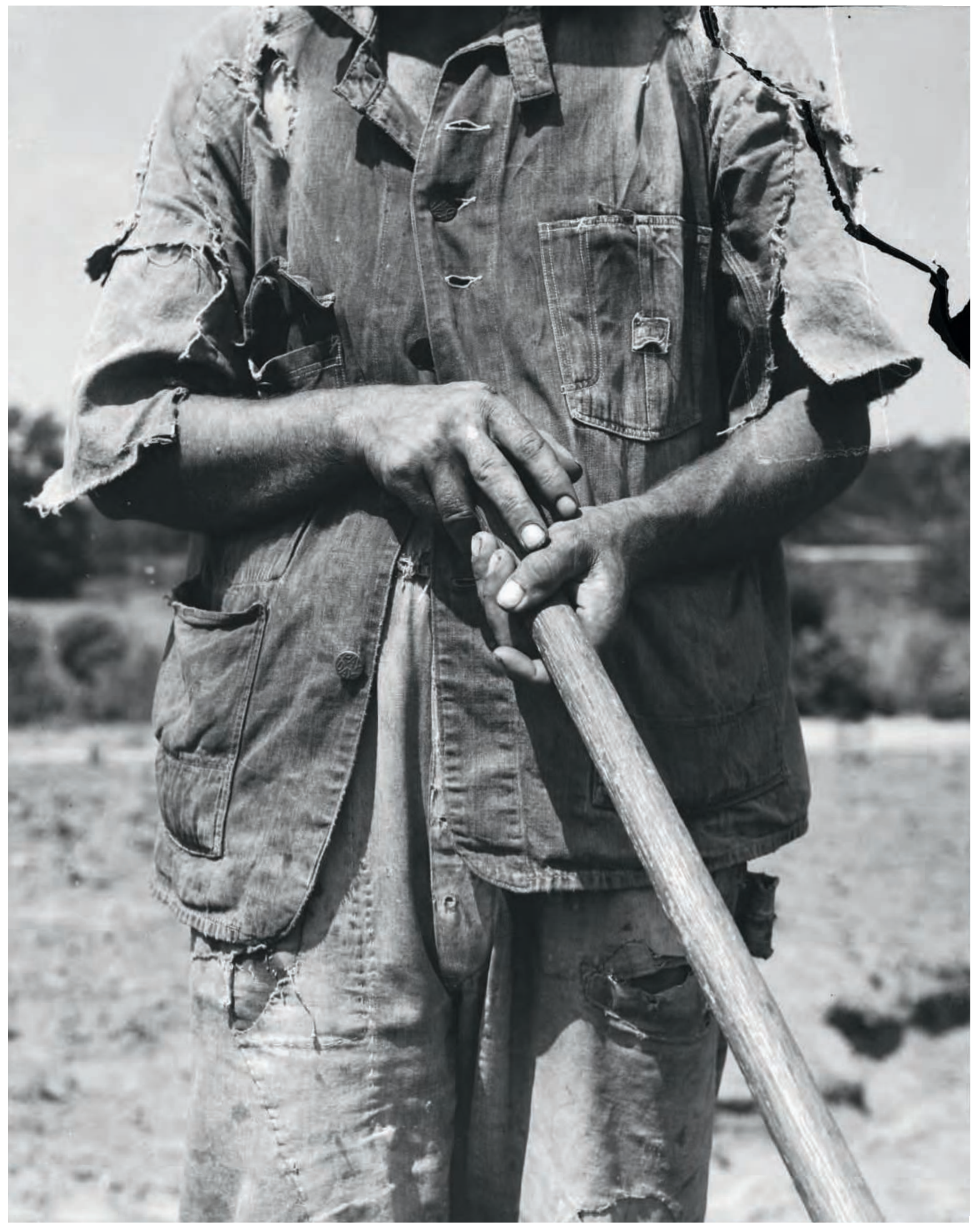


il a même été jusqu'à choisir une photographie de Dorothea Lange cadrée sur le torse et les mains d'un homme a priori noir (comme suggéré par le texte), qui représente en réalité un métayer blanc (ibid.: 251) (fig. 12). Ce retour à une rhétorique de propagande se retrouve dans d'autres productions documentaires de la fin des années 1930 et du début des années 1940. II témoigne d'une remise en question de l'efficacité du réalisme photographique et de la légitimité d'une approche «objective» du sujet traité. Cette évolution contribue néanmoins au discrédit du genre documentaire social dès la fin des années 1930. Roy Stryker lui-même, responsable de la section photographique de la FSA, commence alors à critiquer le glissement de l'approche des photographes de cette administration vers le misérabilisme et le sentimentalisme ${ }^{\mathbf{6 5}}$.

Si les défenseurs de la communauté afro-américaine présentés ici partagent un même but - celui de contrer durablement une image dégradante de ses membres -, les réponses apportées sont diverses, voire contradictoires. Elles révèlent des conceptions différentes de leur histoire, de leur identité et de leur place dans la société contemporaine. Les choix iconographiques de l'anthologie Negro de Cunard sont le parfait exemple des réflexions en cours, en ce début $d u x^{e}$ siècle, sur la légitimité et la justesse d'un regard qui, lui aussi, ne cesse de se chercher.

Musée national d'art moderne - Centre Pompidou, Paris. jones.jmc@gmail.com
65. Sur cette question, voir Lugon 2001: 102-103, 112-114, 365-373.

\section{ci-contre}

fig. 12

Dorothea Lange, Hoe culture. Alabama Tenant Farmer near Anniston, juin 1936. Library of Congress, Prints \& Photographs Division FSA/OWI Collection [LC-USF34-009328-C]

\section{remerciements}

Je remercie chaleureusement Sarah Frioux-Salgas de m'avoir donné la possibilité d'approfondir les problématiques soulevées par l'anthologie Negro et d'avoir partagé, avec enthousiasme, les recherches qu'elle a menées dans les archives de Nancy Cunard. Merci également à Marc Aufraise et Maïra Muchnik pour leurs relectures avisées. 


\section{Alexander, William}

1981 Film on the Left: American Documentary Film from 1931 to 1942. Princeton, Princeton University Press.

\section{Aubert, Didier}

2005 "Lewis Hine et les images anonymes du Pittsburgh Survey" Études photographiques 17; http://etudesphotographiques. revues.org/758 (consulté le 18 septembre 2013).

\section{Barsam, Richard M.}

1973 Non-Fiction Film: A Critical History. Bloomington et Indianapolis, Indiana University Press.

\section{Campbell, Russell}

1977 «Film and Photo League. Radical cinema in the 30 s", Jump Cut 14 ; http://www.ejumpcut.org/ archive/onlinessays/JC14folder/ FilmPhotolntro.html.

1978 Radical Camera in the United States, 1930-1942: The Work of the Film and Photo League, Nykino, and Frontier Films, thèse de doctorat, Northwestern University.

1984 "Radical documentary in the United States ", in Thomas Waugh (éd.), Show Us Life: Toward a History and Aesthetics of the Committed Documentary. Metsuchen, The Scarecrow Press, Inc. : 69-88.

\section{Carroll, Anne Elizabeth}

2005 Word, Image and the New Negro. Representation and Identity in the Harlem Renaissance. Bloomington et Indianapolis, Indiana University Press.

\section{Chambers, Clarke}

1971 Paul U. Kellogg and The Survey: Voices for Social Welfare and Social Justice. Minneapolis, University of Minnesota Press.

\section{Cooley, Rossa B.}

$1923 a$ "The homes of the free. I. Satisfying afflictions ", The Survey (Graphic Number) LI (1) : 4-12.

1923b «The homes of the free. II. The bandage of love ", The Survey (Graphic Number) LI (2).

$1924 \mathrm{a}$ "The homes of the free. III. From slave hut to home",

The Survey (Graphic Number) LI (7): 340-347.

$1924 \mathrm{~b}$ «The homes of the free. IV. The oncoming generation ",

The Survey (Graphic Number) LI (9) : 465-470.

\section{Cunard, Nancy (éd.)}

1934 Negro Anthology. Londres, Wishart \& Co (rééditions abrégées : Ford, Hugh [éd.], Negro: An Anthology, Frédérick Ungar Publishing Co.,

1970; New York-Londres,

Continuum, 1996/2002).

\section{Dejardin, Fiona M.}

1994 "The Photo League: Left-wing politics and the popular press ", History of Photography XVIII (2): 159-173.

Driskell, David, LeveringLewis, David, Schmidt Campbell, Mary et Wfllis Ryan, Deborah

1994 [1987] Harlem Renaissance Art of Black America. New York, The Studio Museum in Harlem, Abradale Press et Harry N. Abrams.

\section{Entin, Joseph B.}

1999 "Modernist documentary: Aaron Siskind's Harlem Document ", Yale Journal of Criticism XII (2) 357-382.

\section{Evans, Catherine et Klein, Mason (éd.)}

2012 New York's Photo League The Radical Camera 1936-1951. New York-Columbus (Ohio)-New Haven-Londres, The Jewish Museum, Columbus Museum of Art et Yale University Press.

\section{Holloway, Camara Dia}

1999 Portraiture and the Harlem Renaissance. The Photographs of James L. Allen. New Haven, Yale

University Art Gallery.

\section{Locke, Alain (dir.)}

1925a "Harlem Mecca of the New Negro ", The Survey (Graphic Number) LIII (11).

1925b The New Negro,

An Interpretation. New York, Albert and Charles Boni.

\section{Lugon, Olivier}

2001 Le Style documentaire. D'August Sander à Walker Evans 1920-1945. Paris, Macula.

\section{Natanson, Nicholas}

1992 The Black Image in the New Deal: The Politics of FSA Photography. Knoxville, The University of Tennessee Press.

\section{OIIman, Leah}

1994 «The Photo League's Forgotten Past », History of Photography XVIII (2): 154-158.

\section{Raeburn, John}

2006 A Staggering Revolution. A Cultural History of Thirties Photography. Urbana et Chicago University of Illinois Press.

\section{Robbins, Gerald}

1964 «Rossa B. Cooley and Penn School: Social dynamo in a Negro rural subculture, 1901-1930", The Journal of Negro Education XXXIII (1) : 43-51.

\section{Siskind, Aaron, Parks, Gordon et Battle, Maricia}

1991 [1981] Harlem Document: Photographs 1932-1940. Manchester-Washington D.C. Cornerhouse Publications et The National Museum of American Art, Smithsonian Institution.

\section{Spivak, John}

2012 Hard Times on a Southern Chain Gang, introduction par David A. Davis. Columbia, The University of Carolina Press [première édition : Georgia Nigger, New York, Brewer, Warren and Putnam, 1932]

\section{Tucker, Anne}

2011 "Modernism and the left: Paul Strand and the Workers Film and Photo Movement ", in Jorge Ribalta (dir.), The Worker-Photography Movement, 1926-1939. Madrid, Museo Nacional Centro de Arte Reina Sofía: 322-333.

\section{Van Arragon, Elizabeth Jane}

2006 The Photo League: Views of Urban Experience in the 1930s and 1940 s, thèse de doctorat University of lowa.

\section{Ward, Frank}

1934 "The camera as a weapon in the class struggle", manuscrit, Film and Photo League, in Tucker 2011 : 334-335

\section{Wright, Richard et Rosskam, Edwin}

194112 Million Black Voices: A Folk History of the Negro in the United States. New York, Viking Press. page 104 et ci-contre Walker Evans, Flood refugees at mealtime, Forrest City, Arkansas, février 1937, couverture de 12 Black Million Voices: A Folk History of the Negro in the United States, New York, Viking Press, 1941. Library of Congress, Prints \& Photographs Division, FSA/OWI Collection [LC-USF331-009231-M1]. 


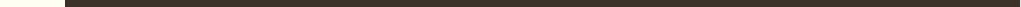

